\title{
Permian (Guadalupian) fusulinids of Bawei Section in Baoshan Block, western Yunnan, China: biostratigraphy, facies distribution and paleogeographic discussion
}

Hao Huang ${ }^{\text {a, b }}{ }^{*}$, Yu-Kun Shi ${ }^{\text {c }}$, Xiao-Chi Jin ${ }^{\text {a, b }}$

\begin{abstract}
Permian fusulinids of the Bawei Section from southern Baoshan Block in western Yunnan, China, adds more data concerning biostratigraphy and paleogeography of this block. These fusulinids comprise 31 species of 11 genera and could be, ascendingly, grouped into two assemblages: Yangchienia-Nankinella assemblage and Chusenella-Rugosofusulina assemblage. The age of both assemblages is determined as late Murgabian-Midian (middle Permian). Regarding taxonomic composition, they are characterized by the dominance of staffellids and rather paucity of neoschwagerinids and verbeekinids, in sharp contrast with coeval fusulinids with prosperous neoschwagerinids and verbeekinids in Nansan-Hewai area, also located in the southern Baoshan Block. Such contemporaneous but disparate taxonomic composition is interpreted as "synchronous but heteropic fusulinid biofacies" due to varying depositional environments. The host rocks of fusulinids in the Bawei area suggest a littoral, restricted shallow marine with low to moderate water circulation,
\end{abstract}


whereas the fusulinid-bearing carbonates in the Nansan-Hewai areas indicate a high-energy open platform. This phenomenon cautions that taxonomic variation might only reflect local sedimentary controls, rather than large-scale paleolatitudes, especially when limited fusulinid data among terranes are utilized for paleogeographic reconstruction.

Keywords: Fusulinid; Baoshan; Permian; Carbonate facies; Paleogeography

\section{Introduction}

The Baoshan Block in western Yunnan, China (Fig. 1) represents a probable Gondwana-derived continental fragment and demonstrates a remarkable switch from cool, Gondwana-affinity to warm, more Tethyan affinity with respect to its Permian fossils and sediments (Jin, 1994; Wopfner, 1996; Wang et al., 2001; Shen et al., 2002; Yan and Liang, 2005; Metcalfe, 2013; Huang et al., 2015a, 2015b). Such drastic switch has been interpreted to reflect the coupled effect of global climatic amelioration and a shift of Gondwana-derived blocks to lower paleolatitude during the Late Paleozoic (Jin, 1994; Shi et al., 1995; Ueno, 2003; Wopfner and Jin, 2009; Metcalfe, 2013). The Permian deposits of the Baoshan Block, therefore, record critical information for understanding the Paleozoic Gondwana disassembly and resultant paleogeographic evolution of the Tethyan region. In this regard, fusulinids are especially valuable for providing both temporal and paleobiogeographic constraints, because they exhibit rapid rates of morphological evolution and sensitivity to environmental variation (Smith and Xu, 1988; Ross, 1995; Kobayashi, 1997; Belasky et al., 2002; Ueno, 2003; Leven, 2004; Davydov and Arefifard, 2007; Zhang et al., 2010, 2013; Davydov et al., 2013).

A wealth of data on Permian fusulinids of the Baoshan Block has been accumulated in past years (Fang et al., 2000; Ueno, 2003; Huang et al., 2009; Shi et al., 2011; Huang et al., 2015a) and was recently reviewed by Huang et al (2015b). In that review, Guadalupian fusulinids newly collected from the Bawei Section in the southern Baoshan Block were briefly reported. These materials are systematically 
studied in present paper and further compared with coeval fusulinids from other sections also in the southern Baoshan Block. Results of this study lend more information to the regional paleogeographic configuration of the Baoshan Block. More significantly, it highlights the necessity to take environmental factors into account, when utilizing limited fusulinid data for large-scale palinspastic reconstruction.

Figure 1 here

\section{Geological setting}

Western Yunnan in southwest China is a geological jigsaw composed of terranes with different tectonic origin. The Baoshan Block lies between the Tengchong Block to the west and Changning-Menglian Belt to the east (Fig. 1A). The Permian of the Baoshan Block comprises siliciclastic sediments with probably glacio-marine diamictites and cool-water fossils in its lower part, and carbonates with faunas suggesting warm water in its upper part (Wang, 1983; Fang and Fan, 1994; Jin, 1994; Wang et al., 2001, 2002; Shen et al., 2002; Jin et al., 2008; Huang et al., 2015a, 2015b). The diamictites and cool-water fossils with Gondwana affinity are the main evidence to restore this block to the northern margin of Gondwana during the Cisuralian (Wang, 1983; Jin, 1994; Wopfner, 1996; Metcalfe, 2013). Subsequently, the appearance of warm-water fossils (e.g., massive wentzellophyllums of corals, diverse fusulinids) as well as carbonate facies of photozoan association signified a climatic warming through the late Cisuralian to Gudalupian (Wang et al., 2001; Shen et al., 2002; Yan and Liang, 2005; Wopfner and Jin, 2009; Huang et al., 2015b).

Correspondingly, Cisuralian fusulinids are rather low in diversity and devoid of large, spherical pseudoschwagerinids which characterize the warm-water Eastern Tethys; Guadalupian ones are much more diversified and yield neoschwagerinids and verbeekinids which are diagnostically warm-water taxa (Huang et al., 2015a, 2015b).

Fusulinid fossils of this study have been collected from the Shazipo Formation of the Bawei Section (Figs. 1 and 2) in the southern Baoshan Block. The Bawei Section 
is exposed at Bawei Village, which is about $30 \mathrm{~km}$ to the south of Yongde County. In the vicinity of this village, the Permian strata mostly strike NNE-SSW and dip to the SW. They are subdivided into the Dingjiazhai Formation, Woniusi Formation, Yongde Formation, and Shazipo Formation in ascending order. The Dingjiazhai Formation consists mainly of silisiclastics with bioclastic limestones or calcareous mudstones in its top part. This formation is disconformably overlain by the basalts of the Woniusi Formation. Upwards, the Yongde Formation is characterized by variegated silisiclastics in its lower part, and shales and argillaceous limestones in its upper part. The overlying Shazipo Formation represents a thick sequence of carbonates: mainly limestones with minority of dolomitic limestone to dolostone in the lower part, and dolomitic limestone to dolostone in the upper part. We have measured the Bawei Section from the basalts of the Woniusi Formation to the upper part of the Shazipo Formation, and collected abundant fusulinids from the lower part of the Shazipo Formation (Fig. 3).

Figure 2 here

\section{Fusulinid composition and age}

From the collected samples, 31 fusulinid species belonging to 11 genera are identified, i.e., Yangchienia, Nankinella, Chusenella, Neofusulinella, Staffella, Xiaoxinzhaiella, Kahlerina, Rugosochusenella, Schwagerina, Rugosofusulina, and Neoschwagerina. One distinct compositional feature of these fusulinids is the dominance of staffellids and the rather paucity of verbeekinids and neoschwagerinids which are common elements for the Guadalupian Tethyan region (e.g., South China and Indochina). Based on overall stratigraphic distribution, the majority of these fusulinids could be, ascendingly, grouped into the Yangchienia-Nankinella assemblage (Sample B2-8 14) and the Chusenella-Rugosofusulina assemblage (Sample B2-20 29) (Fig. 3). Besides, sporadic fusulinids also occur in the level Sample B2-2, including Neoschwagerina sp. indet. and abundant fragments of staffellids. One almost sagittal section of Neoschwagerina sp. indet. possesses axial 
septula as early as in the 4th volution and two axial septula between primary septa in outer whorls. This developmental pattern of axial septula reveals that this specimen is transitional between primitive (e.g., $N$. simplex) and advanced forms (e.g., $N$. margaritae) in the Neoschwagerina phylogeny. Accordingly, this Neoschwagerina specimen of the Sample B2-2 very likely suggests a late Murgabian age.

Figure 3 here

The Yangchienia-Nankinella assemblage consists of abundant Yangchienia, Nankinella, and Neofusulinella, associated with subordinate Chusenella, Staffella, Kahlerina, Xiaoxinzhaiella, and Rugosochusenella (Figs. 4-6). One noticeable feature of this assemblage is, hence, the dominance of staffellids, which includes the major constituents Nankinella and Neofusulinella, as well as associated Staffella. Species of Yangchienia, widespread in Middle Permian Tethyan region, are significant for dating this assemblage. For instance, both $Y$. thompsoni Skinner and Wilde, $1966 \mathrm{~b}$ and $Y$. haydeni Thompson, 1946 occur in the Murgabian-Midian strata in Sicily, Thailand, Transcaucasus, Turkey, Afghanistan, Iran, Crimea, and China (Skinner and Wilde, 1966b; Sheng and Sun, 1975; Toriyama, 1975; Toriyama and Kanmera, 1979; Nie and Song, 1983; Kotlyar et al., 1989; Leven and Okay, 1996; Leven, 1997; Kobayashi and Ishii, 2003) (Please refer to "Occurrence" in the chapter of "6. Systematic paleontology" for details on occurrence and stratigraphic range of each species). $Y$. hainanica Sheng, 1965 has a relatively wider age range and was initially reported from the Eding Formation (late Kubergandian-Murgabian) in Hainan Island, China (Sheng, 1965). It has also been known from late Bolorian-early Murgabian strata in Transcaucasus (Leven, 1987, 1998), Murgabian deposits in Thailand (Toriyama and Kanmera, 1979), and Midian deposits in Tibet, China (Zhang, 2008). Besides, Chusenella xarlensis Wang and Zhou, 1986 has been previously reported from Murgabian-Midian sediments in Tibet, China and Transcaucasus (Wang and Zhou, 1986; Kotlyar et al., 1989). According to Huang et al. (2015a), the Xiaoxinzhaiella has been hitherto confined in Murgabian-Midian strata in western Yunnan (Shi et al., 
2005; Huang et al., 2009), Murgabian sediment in Tibet and Central Iran (Wang et al., 1981; Kobayashi and Ishii, 2003), and Midian strata of south Afghanistan (Leven, 1997). The remaining Kahlerina and Neofusulinella are also common in the Tethyan region during the Murgabian-Midian time (e.g., Sheng, 1963; Vachard and Miconnet, 1989; Zhou and Sheng, 1994; Leven and Okay, 1996; Leven, 2004; Kobayashi, 2011, 2012). Another significant age constraint is that this assemblage could not be older than Neoschwagerina sp. indet. of late Murgabian age, based on their stratigraphic relationship. Taking all these into account, we regard the Yangchienia-Nankinella assemblage to be late Murgabian-Midian in age.

In contrast, the overlying Chusenella-Rugosofusulina assemblage contains abundant Chusenella, Rugosofusulina, and Rugosochusenella, but is devoid of staffellids. Elements of Chusenella in this assemblage, i.e., Chusenella tieni (Chen, 1956), C. quasidouvillei Wang and Zhou, 1986, and C. wuhsüehensis (Chen, 1956), commonly occur in the Maokou Formation (approximately late Murgabian-Midian) in South China or equivalent strata in Tibet, although some of them are also present in the Kubergandian Misellina Zone (Chen, 1956; Sheng, 1963; Zhang, 1982; Wang and Zhou, 1986; Xiao et al., 1986). C. tieni can be also found in the Kubergandian-lower Murgabian in Pamir (Leven, 1967) and Murgabian Bamian limestone in north Afghanistan (Leven, 1997). The Yangchienia haydeni in the lower part of the present assemblage suggests a Murgabian-Midian age as previously discussed. Above the Chusenella-Rugosofusulina assemblage, a particular foraminiferal Shanita fauna is easily recognized with hand lenses at outcrops of the dolomitic limestones in the upper part of the Shazipo Formation (Fig. 3). The Shanita fauna is diagnostic for the Murgabian-Midian and occasionally extends into lower Dzhulfian in the Gondwana-derived blocks (Jin and Yang, 2004). Judging from these, we assign a late Murgabian-Midian age to the Chusenella-Rugosofusulina assemblage. More precise dating of these two assemblages, however, is difficult, as index fusulinid taxa delineating middle Permian stages are absent, e.g., species of Verbeekina, Neoschwagerina, Yabeina, Lepidolina, Sumatrina, and Metadodoliolina (Leven, 2004). 
Figure 4 here

Figure 5 here

Figure 6 here

\section{Facies distribution and paleogeographic discussion}

Of interest is that our studied fusulinids differ markedly from their counterparts in the Nansan and Hewai areas, which are also in the southern Baoshan Block and to the southwest of the Bawei Section (Fig. 1B). In the Murgabian-Midian strata of the Hewai and Nansan areas, verbeekinids and neoschwagerinids are diverse and accompanied by minor staffellids (Huang et al, 2009, 2015a, 2015b). We ascribe such taxonomic discrepancy to varying sedimentary environment on the basis of the following reasons. Previous paleoecological summaries concluded that the staffellids could survive and even prosperously dominate littoral, shallow marine with restricted water circulation, where environments are to certain degree stressful for most other fusulinids (Ross, 1982; Wang et al., 1982; Zhou and Sheng, 1994). Owing to the frequent dolomitization and silification in the restricted littoral marine, the four-layered Fusulinella-type spirotheca of staffellids is often severely obliterated (Zhou and Sheng, 1994). Recent case studies, for instance, on collections from Spain, Russia or Tibet verified this ecological preference of staffellids (Villa and Bahamonde, 2001; Huang et al., 2007; Zhang et al., 2010; Baranova et al., 2014).

The distribution of staffellids in the Bawei Section (Figs. 3 and 7) accords well with the ecological conclusion discussed above. Firstly, X-ray differentiation analysis reveals that the carbonates yielding abundant staffellids of the Yangchienia-Nankinella assemblage have dolomite content mostly over 33\% (Fig. 7). In some thin sections of these carbonates, the euhedral rhomboidal dolomites are conspicuous in matrix and within fusulinid shells (c in Fig. 7). Upwards, the host carbonates of the Chusenella-Rugosofusulina assemblage lacking staffellids are 
mostly pure limestone (maximum $<5 \%$ dolomite). The wall structure of the studied staffellids is also severely altered. The initially differentiated dark tectum and translucent diaphanotheca of these specimens are usually obscured and the whole spirotheca may even change into one undifferentiated thick and murky grey layer (Fig. 4A-K, P).

Figure 7 here

From the viewpoints of carbonate facies, staffellids are confined in wackestone/packstone, which is situated above the calcimudstone at the base and below the upper part of the Chusenella-Rugosofusulina assemblage. The basal calcimudstone is composed of homogeneous sea-floor allomicrite and, in less quantity, microspar, deposited in calm shallow marine (a in Fig. 7). Upwards, peloidal or skeletal wackestone to packstone persists until the middle part of the Chusenella-Rugosofusulina assemblage (c-f in Fig 7). As previously introduced, these wackestone and packstone are oftentimes dolomitized to varying degree, even forming dolostone in the interval separating these two fusulinid assemblages. The matrix of these wackestone to packstone is mainly sea-floor allomicrite, although it could be partially recrystallized to microspar or pseduospar. At some levels, the packstone might be mistaken as grainstone when initially checked at low magnification (d in Fig. 7). Detailed scrutiny under high magnification (e in Fig. 7), however, reveals that spar cements in these ostensible "grainstones" are dusty with curvy crystal boundaries and embedded with micritic relics, thus are more reasonably explained as diagenetic pseudospar. Bioclasts in the wackestone to packstone consist of fusulinids, smaller foraminifera (e.g., Pachyphloia, Agathammina, Hemigordiopsis), echinoids, algae (e.g., Phyloid, abundant Ungadarella), and fewer brachiopods, bivalves, gastropods, and bryozoans. Non-skeletal grains include mainly peloids and aggregate grains. All carbonate grains are poor in both sorting and rounding, while skeletal grains are often abraded or even fragmented. These sedimentary fabrics altogether indicate a shallow, somewhat restricted carbonate platform. The often 
dolomitic condition meanwhile probably suggests a littoral position prone to dolomitization (Flügel, 2010).

Also merit clarification is that the tests of staffellids are often abraded or fragmented ( $\mathrm{d}$ and $\mathrm{h}$ in Fig. 7). Through the broken outermost test wall, the micrite had infilled the inner whorls of fusulinid tests ( $\mathrm{g}$ in Fig. 7) before encrustation over the whole shell. These reveal that transportation and/or turbulence are, to certain degree, involved in their postmortem deposition. A long-distance redeposition of staffellids, yet, could be generally ruled out. First of all, the sedimentary structures for severe transportation are not observed, e.g., uniform sorting and good rounding, current-generated cross-bedding or parallel orientation of grains etc. Moreover, staffellids are dominant in abundance in the Yangchienia-Nankinella assemblage. Kidwell and Bosence (1991) nonetheless pointed out that exotic fossils often comprised only a minority of individuals in the assemblages receiving them. More importantly, the close correspondence between staffellids and facies of littoral, restricted shallow marine are in good agreement with habitat requirement of staffellids. Inasmuch as these facts, we are inclined to regard these staffellids to be at least paraautochthonous within their life habitat, if not completely in situ.

Facies type changes into, in the upper part of the Chusenella-Rugosofusulina assemblage, skeletal grainstone and minor packstone with moderately sorted abundant aggregate grains, fusulinids, and smaller foraminifera, accompanied by fewer echinoids, intraclasts, and brachiopods (h in Fig. 7).The moderate sorting, inclusion of intraclasts, and general absence of micrite altogether indicate relatively good water circulation in open platform. Dolostone occupies the top of the measured section (i in Fig. 7).

In comparison, rocks containing abundant neoschwagerinids and verbeekinids in the Hewai and Nansan areas are packstone to grainstone with majorly sparitic matrix and interbedded with ooid grainstone. An open, shallow marine with water agitation thus was deduced for the habitat of these neoschwagerinids and verbeekinids (Huang et al., 2015a). Therefore, the taxonomic difference of the Murgabian-Midian fusulinids between the Bawei area and the Nansan-Hewai areas probably corresponds 
to varying sedimentary environments. A littoral, restricted shallow platform in the Bawei area, susceptible to dolomitization, accommodated a particularly hospitable habitat for the staffellids, but not very optimal for other fusulinid genera, such as elements of neoschwagerinids and verbeekinids (Fig. 8). A similar paleogeographic reconstruction concerning the Bawei and Hewai-Nansan areas has been proposed from more thorough multi-disciplinary data during the geological survey at 1:50 000 scale (Geological Survey Team of Yunnan, 1990).

This comparative study again validates the delicate sensitivity of fusulinids to sedimentary factors. Coeval but disparate fusulinid faunas due to varying depositional environments have been recognized across the world (e.g., Ross, 1965, 1969; Wang et al., 1982; Dawson and Racey, 1993; Wu and Yang, 1998; Baranova and Kabanov, 2003; Della Porta et al., 2005; Baranova et al., 2014), and could be termed "synchronous but heteropic biofacies". Even so, it has not received proper attention, when fusulinids are utilized for paleogeographic reconstruction. Variance between fusulinids among terranes with respect to diversity or generic composition, especially presence or absence of verbeekinids and neoschwagerinids, are commonly invoked to explain seawater temperature, which in turn is very likely controlled by paleolatitudes. In the situation of "heteropic biofacies", it is evident that taxonomic discrepancy of fusulinid faunas might only reflect local sedimentary factors, rather than large-scale paleogeographic controls. It should be especially cautious when only limited fusulinid data from few sections are testable from each block. For instance, Permian fusulinids in a few Peri-Gondwana blocks have been hitherto only reported from scattered localities, e.g., Tengchong Block (Shi et al., 2008), Shan State of Myanmar (Latt and Ueno, 2008). Therefore, contemporary fusulinids from different terranes but the same sedimentary setting is a prerequisite for comparison to further gain paleolatitudinal information. More reasonable palinspastic reconstruction can only be achieved when data from multiple sections of varying environments in each region are compiled.

Figure 8 here 


\section{Conclusions}

1. Systematic study documents 31 fusulinids of 11 genera from the Bawei Section in the southern Baoshan Block, western Yunnan. Among them, two assemblages have been recognized ascendingly: 1) Yangchienia-Nankinella assemblage characterized by abundant staffellids; 2) Chusenella-Rugosofusulina assemblage dominated by the two eponymous genera. Both these two assemblages are dated late Murgabian-Midian of middle Permian.

2. Further comparison between these fusulinids from the Bawei area and their coevals from the Nansan and Hewei areas demonstrates a good case of "synchronous heteropic fusulinid biofacies". The dominance of staffellids and rather paucity of neoschwagerinids and verbeekinids in the Bawei area are interpreted to result from a littoral, restricted shallow marine, versus open platform for abundant neoschwagerinids and verbeekinids in the Nansan and Hewai areas.

3. Taxonomically variant fusulinids among terranes might be controlled by local environmental conditions thus do not necessarily reflect paleolatitudinal configuration. This emphasizes that fusulinid data at least from the same sedimentary setting or at best from varying sedimentary environments should be garnered from each terrane for a reasonable paleogeographic reconstruction.

\section{Systematic paleontology}

Classification schemes of Loeblich and Tappan (1988) and Sheng et al. (1988) are critically adopted here. All samples and thin sections are housed in the Institute of Geology, Chinese Academy of Geological Sciences.

Superfamily FUSULINACEA Möeller, 1878

Family SCHUBERTELLIDAE Skinner, 1931

Subfamily Schubertellinae Skinner, 1931 
Genus Yangchienia Lee, 1933

Diagnosis: Early volutions discoidal followed by later fusiform whorls. Wall with tectum, diaphanotheca and obsolete tectoria. Tunnel bordered by robust and wide chomata.

Yangchienia thompsoni Skinner and Wilde, 1966b

(Fig. 4S)

1966b Yangchienia thompsoni-Skinner and Wilde, p. 7, pl. 4, figs. 11, 12.

1975 Yangchienia thompsoni - Sheng and Sun, p. 11, pl. 12, figs. 9, 10.

1975 Yangchienia thompsoni-Toriyama, p. 11, pl. 1, figs. 17, 18.

1979 Yangchienia thompsoni - Toriyama and Kanmera, p. 36, pl. 4, figs. 15-22.

1983 Yangchienia thompsoni-Nie and Song, pl. 6, fig. 4.

1989 Yangchienia thompsoni-Kotlyar et al., pl. 5, figs. 1, 5.

1996 Yangchienia thompsoni - Leven and Okay, pl. 7, fig. 13.

1997 Yangchienia thompsoni - Leven, p. 61, pl. 3, fig. 10.

Description: Shell fusiform with vaulted median portion and blunt poles. 8.5 volutions, $2.7 \mathrm{~mm}$ long and $1.75 \mathrm{~mm}$ wide with form ratio 1.55:1. Proloculus spherical and $0.06 \mathrm{~mm}$ in diameter. Initial two volutions discoidal, coiling in endothyroid pattern. Septa moderately folded in polar area. Asymmetrical chomata abruptly reduced in height at ca. 1/4 distance from the tunnel to the poles. Axial fillings poor and restricted in polar area.

Remarks: This specimen is identical to $Y$. thompsoni in terms of test shape, form ratio, proloculus diameter, and chomata pattern, but with slightly smaller size. The $Y$. thompsoni closely resembles Y. haydeni Thompson, 1946, but differs in larger test, smaller form ratio, and the abrupt reduction of chomata height at about 1/4 of the distance from the tunnel to the poles.

Occurrence: Shazipo Formation (Murgabian-Midian) of the Bawei Section in southern Baoshan Block, China; Maokou Formation (approximately late 
Murgabian-Midian) in Qinghai Province, China; Longge Formation

(Murgabian-Midian) of Rutog Town in Tibet, China; middle Permian Sosio limestone block in the Sosio Valley in Sicily; Presumatrina schellwieni Zone (Murgabian) in Sara Buri and Afghanella Zone (Murgabian) in Khao Khao Formation of Sara Buri limestone, Central Thailand; Arpian Formation (Midian) of Transcaucasus; Hodul Unit of Permian exotic limestone block in NW Turkey; Midian limestone of Suleiman-Kirthar area in south Afghanistan.

Yangchienia haydeni Thompson, 1946

(Fig. 4L, Q)

1946 Yangchienia haydeni-Thompson, p. 146, pl. 23, figs. 5-11.

1963 Yangchienia haydeni-Sheng, p. 37, pl. 5, figs. 10.

1975 Yangchienia haydeni - Sheng and Sun, p. 11, pl. 1, fig. 25.

1975 Yangchienia haydeni-Toriyama, p. 8, pl. 1, figs. 8-12.

1981 Yangchienia haydeni - Wang et al., p. 28, pl. 11, figs. 3, 6, 7.

1982 Yangchienia haydeni - Zhang, p. 158, pl. 23, figs. 10, 11, 13, 14, 16, non 5.

1985 Yangchienia haydeni - Sun and Zhang, p. 507, pl. 2, figs. 7, 8, 11.

1986 Yangchienia haydeni - Zhang and Dong in Xiao et al., p. 80, pl. 2, figs. 7, 9-10.

1997 Yangchienia haydeni-Leven, p. 61, pl. 3, fig. 12.

Description: Shell fusiform with bluntly pointed poles. 7.5-9 volutions, $2.25-3.33 \mathrm{~mm}$ long and1.19-1.79 mm wide with form ratio 1.66-2.27:1. Proloculus spherical and 0.05-0.07 $\mathrm{mm}$ in diameter. The coiling axis of initial volutions is nearly perpendicular to that of the later whorls. Septa very poorly folded in polar ends. Chomata about 2/3 as high as respective chamber. Axial fillings absent or rather poor in polar area. Remarks: Although Thompson (1946) suggested that this species had sharply pointed poles, the poles of inner volutions in the originally illustrated specimens are bluntly pointed. The outermost poles are pointed in the original illustration, but seem to be 
caused by erosion.

Occurrence: Shazipo Formation (Murgabian-Midian) of the Bawei Section in southern Baoshan Block, China; Maokou Formation of Qinghai, Guizhou and Guangxi, China; Murgabian Mangcuo Formation and Wenbu Formation in Qamdo Block and Lhasa Block of Tibet, China; Murgabian Kaerwa Formation in Ruoqiang of Xinjiang, China; Presumatrina schellwieni Zone (Murgabian) in Sara Buri of Central Thailand; Murgabian Bamian limestone of northern Afghanistan; Murgabian Abtchagan Formation in south Afghanistan.

Yangchienia hainanica Sheng, 1965

(Fig. 4N, O)

1965 Yangchienia hainanica - Sheng, p. 567, pl. 2, figs. 8, 9, 11.

1979 Yangchienia hainanica - Kahler and Kahler, p. 231, pl. 4, fig. 5.

1979 Yangchienia hainanica - Toriyama and Kanmera, p. 34, pl. 4, figs. 5-14.

1981 Yangchienia hainanica - Toriyama in Sugiyama and Toriyama, p. 10, pl. 3, figs. $1,2$.

1987 Yangchienia hainanica-Leven, pl. 2, figs. 2, 3.

1992 Yangchienia hainanica-Zhang, pl. 1, figs. 1, 4.

1998 Yangchienia hainanica - Leven, pl. 2, figs. 29-32.

2008 Yangchienia hainanica - Zhang, p. 106, pl. 20, figs. 14-16.

Description: Shell fusiform with 7-8 volutions. 1.22-1.61 mm long and 0.75-0.93 mm wide with form ratio $1.58-1.81: 1$. Proloculus $0.05-0.06 \mathrm{~mm}$ in diameter. The early coiling axis is nearly perpendicular to that in mature stage. Septa plane. Chomata massive and asymmetrical, about $2 / 3$ as high as respective chamber in median portion. Axial fillings absent.

Remarks: In terms of relatively small size, this species is similar to $Y$. compressa (Ozawa, 1927), Y. iniqua Lee, 1933, and Y. kwangsiensis Chen, 1956. It could be easily differentiated from $Y$. compressa by a much smaller form ratio, and from $Y$. 
iniqua by blunt poles. $Y$. kwangsiensis differs the present species in particularly thin spirotheca.

Occurrence: Shazipo Formation (Murgabian-Midian) of the Bawei Section in southern Baoshan Block, China; Eding Formation of Hainan Island, China, late Chihsian-early Maokouan (approximately late Kubergandian to Murgabian); Xilanta Formation (Midian) in Pulan area of Himalaya in southern Tibet, China;

Afghanella-Pseudodoliolina Zone (Murgabian) in Khao Khao Formation of Sara Buri limestone in Central Thailand; middle Permian of Anatolien in Turkey; Asni Formation (late Bolorian-early Murgabian) in Transcaucasus.

Yangchienia aff. haydeni Thompson, 1946

(Fig. 4M, R)

Description: Shell fusiform with 7-8 volutions, 1.84-2.25 mm long and 0.88-1.19 mm wide with form ratio $1.74-2.27: 1$. Proloculus $0.05-0.07 \mathrm{~mm}$ in diameter. Initial coiling axis is oblique to later one. Chomata massive and high, steep on the tunnel side, gently extends to the poles. Axial fillings poor, forming a restricted narrow band along the coiling axis.

Remarks: These specimens are very similar to $Y$. haydeni, but with obviously smaller size.

Family FUSULINIDAE Möeller, 1878

Subfamily Staffellinae Miklukho-Maclay, 1949

Remarks: The taxonomic status of staffellids remains debatable, because of discrepant opinions on the spirothecal structure (Ross, 1982; Groves, 1991; Zhou and Sheng, 1994; Zhou et al., 2000). The spirotheca of Staffellids are usually recrystallized into vaguely differentiated condition. Some students attribute this to original aragonite as test mineralogy (Ross, 1982; Groves, 1991; Ueno, 2001), whereas others insisted that staffellids have Fusulinella-type wall with tectum, diaphanotheca, and inner and outer tectoria (Zhou and Sheng, 1994; Zhou et al., 2000). Even in one same sample of our 
collection, the spirotheca of staffellids is severely altered, while that of Yangchienia and Chusenella well retains original texture. Such selective diagenetic alteration seems to substantiate that shell of staffellids is different from that of the majority of fusulinids and possibly aragonitic. Meanwhile, some well-preserved specimens of staffellids do have wall quite similar to four-layered Fusulinella-type. It seems unreasonable to separate otherwise identical specimens with diagenetically altered or well-preserved wall structure into different genera. Therefore, we tend to believe that the pristine spirotheca of staffellids may be aragonitic, meanwhile also differentiated in a pattern similar to Fusulinella. To clarify the definite texture of their spirotheca yet awaits further detailed study. The metastable aragonite is prone to dissolution and subsequent diagenetic modification, especially in restricted shallow marine liable to mixture of meteoric and normal seawater. The usually obliterated tests of staffellids in rocks probably are caused by the convergence of aragonitic mineralogy and particular living environment favored by staffellids.

Genus Nankinella Lee, 1933

Diagnosis: Test lenticular to discoidal with acute or moderately acute periphery. Spirotheca might be originally four-layered with tectum, thick diaphanotheca, and discontinuous tectoria. Wall structure often destructed by replacement or recrystallization. Tunnel, chomata and occasional foramina present.

Nankinella cf. longgensis Nie and Song, 1983

(Fig. 4H, I)

Description: Shell with pointed periphery, steep lateral slopes and slightly depressed umbilici. 7-8 volutions, $1.38-1.81 \mathrm{~mm}$ long and 3.19-4.04 $\mathrm{mm}$ high with form ratio 0.44-0.55:1. Proloculus $0.07-0.12 \mathrm{~mm}$ in diameter. Initial few volutions discoidal with blunt periphery and later ones lenticular with pointed periphery. Chomata not observed.

Remarks: These specimens closely resemble $N$. longgensis, only differing in slightly 
larger size and concave umbilici. However, such concave poles might be caused by erosion.

Nankinella cf. nanjiangensis Zhang and Wang, 1974

(Fig. 4G)

Description: Shell robust lenticular with narrowly rounded periphery, steep lateral slopes and slightly convex umbilici. 8.5 volutions, $3.00 \mathrm{~mm}$ long and $4.80 \mathrm{~mm}$ high with form ratio $0.63: 1$. Proloculus unseen. Inner volutions lenticular with pointed periphery and strongly convex umbilici. In outer volutions, the periphery narrowly rounded and umbilici gently convex. Chomata unseen.

Remarks: This specimen is generally identical to $N$. nanjiangensis, only differing in fewer volutions and smaller size.

Genus Neofusulinella Deprat, 1912 emend. Zhou and Sheng, 1994

Diagnosis: Test robust fusiform with bluntly pointed poles and early lenticular volutions. Spirotheca seems originally four-layered Fusulinella-type, but often obscured due to diagenesis. Tunnel and chomata well developed with occasional foramina.

Remarks: The definition of this genus is in much confusion, which results mostly from divergent understanding of its spirothecal structure. When establishing Neofusulinella as a new genus, Deprat (1913) stated that it differs from Fusulinella only by elongated fusiform shape on the one hand, and mentioned that its wall was composed of tectum and alveolar layer on the other hand. Unfortunately, the illustrations provided by him fail to show distinct keriotheca. Subsequently, the test of Neofusulinella is often reported to be recrystallized and composed of tectum and inner unclear layer which faintly hint fine alveolar texture (Dunbar and Skinner, 1937; Thompson and Foster, 1937; Thompson, 1948). Zhou and Sheng (1994) contended that wall of Neofusulinella is probably Fusulinella-type and recrystallization for Neofusulinella and staffellids (e.g., Nankinella and Staffella) are exactly the same. 
Their viewpoint seems to be supported by our observation. Among our studied specimens, the spirotheca of Neofusulinella and Nankinella, which are blurred by diagenesis, could not be differentiated from each other. This is the main reason for us to tentatively include Neofusulinella into Subfamily Staffellinae. The possibility that the test of Neofusulinella is composed of tectum and rudimentary alveolar structure, however, could not be fully excluded at present. To us, the only cogent case showing clear alveolar structure in Neofusulinella is provided by Toriyama et al. (1969). Zhou and Sheng (1994) argued that ambiguous alveolar structure in Neofusulinella could also be found in staffellids and might be of diagenetic origin, but did not elaborate the mechanism of such diagenetic processes.

Ueno (2001) established a new genus Jingzhangia, which is closely similar to Neofusulinella. The main reason for Ueno to justify Jingzhangia is: 1) the moderately thick wall was completely replaced and in some portion composed of tectum, diaphanotheca, and inner darker layer; 2) the small pores at the base of septa were interpreted to be septal pores. As discussed above, the replacement is not a novel phenomenon, but has been repeatedly reported for Neofusulinella. On the other hand, the small pores located at the basal septa might be more reasonably considered foramina, as septal pores are often smaller and irregularly distributed across the septa in both modern and ancient foraminifera (Hottinger, 2006). Similar foramina were clearly shown by Zhou and Sheng (1994) in not only Neofusulinella but also holotypes of several species of staffellids. We tend to, consequently, suppress Jingzhangia as a synonym of Neofusulinella, unless the keriotheca in Neofusulinella could be confirmed in the future.

Neofusulinella subglobosa Huang, 2010

(Fig. 4B, C, E, F, K)

Description: Shell robust subspherical with slightly vaulted median portion, gentle lateral slopes and blunt poles. 7.5-10 volutions, 4.23-5 mm long and 3.68-4.62 mm wide with form ratio 1.08-1.22:1. Proloculus not well demonstrated, probably small 
and with diameter less than $0.3 \mathrm{~mm}$. Initial volutions discoidal with blunt periphery and subsequent ones quickly expand in terms of chamber height, while intermediate ones robust fusiform in shape. No septal folding observed. Triangular and low chomata distinct, approximately as high as 1/5 of respective chamber. Median tunnel wide. Foramina and accompanied parachomata conspicuous in certain areas at the base of septa. Spirotheca thick and seems similar to four-layered, but obscured due to diagenesis. The thickness of spirotheca in outermost volutions could be $0.6-0.9 \mathrm{~mm}$ in the median region.

Remarks: Zhou and Sheng (1994) argued that only Pseudoendothyra, Nankinella, Staffella, and Neofusulinella are valid genera of the Subfamily Staffellinae, on the basis of a thorough review of all genera pertaining to this subfamily. They also suggested that the criterion for generic classification is the test shape which evolved from lenticular (Pseudoendothyra and Nankinella) through spherical/subspherical (Staffella) to robust fusiform (Neofusulinella). Our material of this species has somewhat subspherical shape, which is reminiscent of Staffella. However, the form ratio of this species is over one throughout its ontogeny. Besides, the innermost volutions of our specimens are discoidal with round periphery, whereas those of Staffella are lenticular with acute periphery. These morphological characteristics suffice to differentiate our samples from Staffella. Compared with other species of Neofusulinella, this species has distinctively smaller form ratio. This species may represent a phylogenetic intermediate between spherical/subspherical Staffella and robust fusiform Neofusulinella.

Occurrence: Shazipo Formation (Murgabian-Midian) of the Bawei Section in southern Baoshan Block, China.

Neofusulinella aff. praecursor Deprat, 1913

(Fig. 4A, D)

Description: Shell robust fusiform with 7-8 volutions. 3.46-5.61 mm long and 2.54-4 mm wide with form ratio 1.27-1.40:1. Proloculus unseen. First 2-3 volutions discoidal 
with rounded periphery. Septa plane. Asymmetrical and low chomata distinct. Foramina visible in certain areas of the shell.

Remarks: Our specimens are rather similar to N. praecursor in terms of shell shape, volution number, but with obviously larger size and smaller form ratio. They could also be easily differentiated from $N$. lantenoisi Deprat, 1913 by the smaller form ratio and larger shell. In addition, $N$. lantenoissi has pointed poles and strongly vaulted median portion.

Neofusulinella cf. subglobosa Huang, 2010

(Fig. 4J)

Description: Shell slightly compressed subspherical with 8 volutions. $3.75 \mathrm{~mm}$ long and $3.16 \mathrm{~mm}$ wide with form ratio 1.18:1. Proloclus small followed by several discoidal volutions, intermediate volutions robust fusiform with pointed poles and adult whorls subspherical. Septa unfluted. Chomata very small and tunnel wide. Remarks: This specimen is similar to N. subglobosa in terms of shell shape, volution number, but has a much smaller size.

Genus Staffella Ozawa, 1925, emend. Zhou and Sheng, 1994

Diagnosis: Juvenile volutions lenticular with acute periphery followed by subspherical to spherical tests in mature stage. Wall structure similar to Nankinella. Tunnel well developed with less developed chomata and occasional foramina.

\section{Staffella sp.}

(Fig. 4P)

Description: Shell subspherical with round periphery and generally flat umbilici. 7 volutions, $2.28 \mathrm{~mm}$ long and $2.35 \mathrm{~mm}$ wide with form ratio $0.97: 1$. Proloculus spherical and $0.11 \mathrm{~mm}$ in diameter, inner volutions lenticular with narrow periphery. Remarks: This specimen is very similar to S. moellerana Thompson, 1935, but the 
latter has concave umbilici and smaller width of corresponding volution.

Family SCHWAGERINIDAE Dunbar and Henbest, 1930

Subfamily Pseudoschwagerininae Zhang, 1963

Genus Chusenella Hsu, 1942, emend. Chen, 1956

Diagnosis: Test robust fusiform to elongate fusiform, early whorls tight and later ones loose. Septa plane in juvenarium and tightly fluted later. Wall with tectum and keriotheca. Chomata rudimentary in inner volutions or completely absent. Axial fillings often heavy.

Remarks: This genus is diagnosed on the tightly coiled juvenarium, obsolete chomata, and absence of septal folding in first few volutions (Chen, 1956; Stewart, 1963). Based on the type species Chusenella ishanensis Hsu, 1942, only specimens with rather compact juvenile volutions were initially identified as Chusenella (Hsu, 1942; Chen, 1956). Some specimens previously identified as Schwagerina or Pseudofusulina demonstrate no septal flution in juvenarium, but possess not as tight inner whorls as $C$. ishanensis. These specimens were also incorporated into Chusenella by Stewart (1963). Following Stewart's opinion, the essential distinction between these two genera is the unfluted septa in juvenile stage of Chusenella. Accordingly, some species of Chusenella could closely resemble Schwagerina in terms of test shape, spirotheca, and coiling pattern.

Chusenella quasidouvillei Wang and Zhou, 1986

(Fig. 5M, P, R)

1986 Chusenella quasidouvillei - Wang and Zhou, p. 142, pl. 1, fig. 1-5.

Description: Shell inflated fusiform to fusiform with bluntly pointed poles. The lateral poles become a bit concave near the poles. 8-9 volutions, 4.28-5.96 $\mathrm{mm}$ long and 2.12-2.82 mm wide with form ratio 1.83-2.15:1. Proloculus spherical, 0.07-0.08 mm 
in diameter. First 3-4 volutions very tight and slender to elongate fusiform, later whorls become inflated and loosely expand into fusiform shape. Septa plane in juvenarium, regularly and tightly folded in later whorls. Septal folds often high and narrow, forming meshwork in polar ends. Chomata weak and tiny in juvenarium, absent in adult stage. Axial fillings distinct in polar and lateral region of test.

Remarks: This species is similar to C. shiqianensis Liu, Xiao and Dong, 1978, but the latter has more volutions and larger size. It also resembles C. quasireferta Chen, 1985 (in Zhang et al., 1985), but slightly differs in more regular septal flution and slightly smaller form ratio.

Occurrence: Shazipo Formation (Murgabian-Midian) of the Bawei Section in southern Baoshan Block, China; Xiala Formation of Xainza area in Lhasa Block of Tibet, China, Maokouan (approximately late Murgabian-Midian).

Chusenella tieni (Chen, 1956)

(Fig. 5I, J)

1956 Schwagerina tieni - Chen, p. 23, pl. 1, figs. 13-16.

1963 Chusenella tieni (Chen) - Sheng, p. 81, pl. 23, figs. 19-23.

1967 Chusenella tieni (Chen) - Leven, p. 156, pl. 14, figs. 5, 6.

1982 Chusenella tieni (Chen) - Zhang, p. 191, pl. 23, figs. 1, 3.

1986 Chusenella tieni (Chen) - Wang and Zhou, p. 144, pl. 1, fig. 8.

1986 Chusenella tieni (Chen) - Zhang and Dong in Xiao et al., p. 132, pl. 15, figs. $13-15,17$.

1997 Chusenella tieni (Chen) - Leven, p. 73, pl. 18, figs. 1, 4.

2008 Chusenella tieni (Chen) - Zhang, p. 126, pl. 30, figs. 18, 19.

Description: Shell fusiform with pointed poles. 5-6.5 volutions, 2.9-3.52 mm long and 1.01-1.27 mm wide with form ratio 2.70-2.87:1. Proloculus spherical and 0.07-0.13 $\mathrm{mm}$ in diameter. First 3-3.5 fusiform volutions very tight with plane septa. Narrow or round septal folds often as high as each chamber in outer volutions. Chomata small in 
inner volutions and absent in adult stage. Axial fillings moderately developed in inner whorls and well developed in polar and nearby lateral portion in outer whorls. Remarks: Although the specimens are also similar to C. dorashamensis Rosovskaya, 1965 in test shape, they could be distinguished by smaller form ratio.

Occurrence: Shazipo Formation (Murgabian-Midian) of the Bawei Section in southern Baoshan Block, China; Qingxichong Limestone (Murgabian) of Hubei Province, China; Maokouan strata of Guizhou and Guangxi, China,; Afghanella schencki Zone (Murgabian) in West Qinling, China; earlier middle Permian of Qamdo Block and Xiala Formation (Murgabian-Midian) in Xainza area in Tibet, China; Bamian limestone (Murgabian) of north Afghanistan; Kubergandian-lower Murgabian strata in Pamir.

Chusenella xarlensis Wang and Zhou, 1986

(Fig. 5N, Q)

1986 Chusenella prompta - Wang and Zhou, p. 143, pl. 2, figs. 8-10.

1986 Chusenella xarlensis - Wang and Zhou, p. 143, pl. 1, figs. 16-19.

1989 Chusenella xarlensis - Kotlyar et al., pl. 5, fig. 12.

Description: Shell fusiform with blunt poles. 7.5-8 volutions, 4.92-5.52 $\mathrm{mm}$ long and 1.72-1.94 mm wide with form ratio 2.81-2.91:1. Proloculus $0.07-0.13 \mathrm{~mm}$ in diameter. Initial 3 volutions rather tight and slender fusiform with plane septa. Septa strongly and somewhat irregularly folded in later whorls. Chomata small in juvenarium and absent in adult stage. Axial fillings moderately developed in polar area in inner whorls and may slightly extend to nearby lateral portion in outer whorls.

Remarks: This species is similar to C. quasireferta Chen, 1985 (in Zhang et al., 1985) and C. quasidouvillei, but differs in somewhat irregular septal folding, as well as larger form ratio. It also resembles $C$. deprati (Ozawa, 1925), but the latter has more regular septal flution and more convex median portion.

Occurrence: Shazipo Formation (Murgabian-Midian) of the Bawei Section in 
southern Baoshan Block, China; Xiala Formation (Murgabian-Midian) in Xainza area of Tibet, China; Hachikskaya Formation and Arpian Formation in Transcaucasus, Murgabain-Midian.

Chusenella wuhsüehensis (Chen, 1956)

(Fig. 5H)

1956 Schwagerina wuhsüehensis - Chen, p. 4, pl. 2, figs. 4-6.

1962 Chusenella wuhsüehensis (Chen) - Sheng, p. 122, pl. 18, fig. 8.

1986 Chusenella wuhsüehensis (Chen) - Wang and Zhou, p. 145, pl. 2, fig. 3.

1986 Chusenella wuhsüehensis (Chen) - Zhang and Dong in Xiao et al., p. 134, pl. 15, figs. 9, 10 .

Description: Shell fusiform with bluntly pointed poles. 6 volutions, $3.46 \mathrm{~mm}$ long and $1.44 \mathrm{~mm}$ wide with form ratio 2.40:1. Proloculus unseen. Initial 3 volutions very tight and slender fusiform with plane septa. In later whorls, septal folds narrowly round, $1 / 2$ to $2 / 3$ as high as respective chamber in median portion, often as high as each whorl in lateral region and forming meshwork in polar ends. Chomata not observed. Axial fillings developed in polar area and nearby lateral portion.

Remarks: This species is similar to C. tieni, but differs in more blunt poles and larger form ratio.

Occurrence: Wuxue Limestone of Hubei Province, Maokouan (approximately late Murgabian-Midian) strata of Guizhou Province and Xiala Formation (Murgabian-Midian) of Xainza are in Lhasa Block of Tibet, China.

Chusenella aff. tieni (Chen, 1956)

(Fig. 5K)

Description: Shell fusiform with bluntly pointed poles. 6-7.5 volutions, 2.85-4.2 mm long and 1.24-1.96 mm wide with form ratio 2.14-2.57:1. Proloculus spherical and 
0.07-0.13 $\mathrm{mm}$ in diameter. Initial 3 volutions very tight and slender fusiform. Septa plane in innermost 3 volutions, and strongly folded with high folds in later volutions. No distinct chomata observed. Axial fillings poor, confined in polar area in inner whorls and may extend to nearby lateral portion in outer whorls.

Remarks: Notwithstanding the similarity between specimens of $C$. aff. tieni and $C$. tieni, the former group could be easily differentiated by their poor axial fillings and smaller form ratio.

Chusenella aff. referta Skinner and Wilde, 1966a

(Fig. 5L)

Description: Shell ellipsoidal with slightly convex median portion which gently sloping into bluntly rounded poles. 6.5-7.5 volutions, 3.47-4.14 $\mathrm{mm}$ long and 1.28-1.95 mm wide with form ratio 2.12-3.17:1. Proloculus 0.09-0.11 mm in diameter followed by 3-4 tightly coiled volutions. Initial whorls elongate with plane septa and later whorls with strong and generally regular septal foldings. Septal folds high and narrow, 2/3 the height of each chamber. Tiny chomata obsolete in inner volutions and absent in outer whorls. Heavy axial fillings cover the polar and lateral region of each volution. Gentle rugosity of the tectum could be observed in some parts of the spirotheca.

Remarks: The specimens are similar to C. referta Skinner and Wilde, 1966a in terms of heavy axial fillings, but clearly differ in the blunt poles and fewer volutions. $C$. quasireferta also possesses heavy axial fillings but differs from the present specimens in more volutions and smaller form ratio.

Chusenella cf. gracilis Rosovskaya, 1965

(Fig. 5F)

Description: Shell fusiform with sharply pointed poles. 5.5 volutions, $4.83 \mathrm{~mm}$ long and $1.51 \mathrm{~mm}$ wide with form ratio $3.20: 1$. Proloculus spherical and $0.13 \mathrm{~mm}$ in 
diameter. Initial 2 volutions very tight and slender fusiform. Septa plane in innermost 2 volutions, gently folded in 3rd volution and strongly, regularly folded in later whorls. Septal folds narrowly round, about 1/2 the height of the respective chamber and forming meshwork in polar ends. Chomata small in inner whorls. Axial fillings developed in polar and nearby lateral portion.

Remarks: Our specimen is very similar to C. gracilis, but differs in fewer volutions and smaller size. It might be an immature specimen of the $C$. gracilis.

\section{Chusenella sp.}

(Fig. 5O)

Description: Shell fusiform with blunt poles. 6 volutions, $2.26 \mathrm{~mm}$ long and $1.25 \mathrm{~mm}$ wide with form ratio 1.81:1. Proloculus $0.07 \mathrm{~mm}$ in diameter. Initial 3 volutions very tight and slender fusiform. Septa plane in innermost 3 volutions, gently folded in $4^{\text {th }}$ whorl and strongly folded in later whorls. Septal folding somewhat irregular, septal folds usually as high as respective chamber and forming meshwork in polar ends. Chomata obsolete in juvenarium. Axial fillings not present.

Remarks: This specimen is characterized by the small size and the absence of axial fillings.

Genus Rugosochusenella Skinner and Wilde, 1965

Diagnosis: Test elongate fusiform with tight juvenarium. Septa plane in earliest whorls and irregularly fluted later. Wall of tectum and coarse keriotheca, and undulated into curvy outline.

Rugosochusenella aff. longjiangensis Lin, 1984

(Fig. 5A, B)

Description: Shell fusiform with blunt poles. 7-7.5 volutions, 5.4-5.54 $\mathrm{mm}$ long and 2.25-2.34 mm wide with form ratio 2.37-2.40:1. Spherical proloculus $0.08-0.1 \mathrm{~mm}$ in 
diameter. Initial 3-4 volutions very tight and slender fusiform with plane septa. Septal foldings regularly spaced, circular and high, often as high as respective chamber in later whorls. Chomata small in innermost volutions and absent in adult stage. Axial fillings well developed in polar and nearby region throughout the ontogeny. Rugosity and undulation of spirotheca could be observed in all volutions.

Remarks: These specimens are rather similar to Rc. kalaikuchnensis Davydov, 1986 and Rc. longjiangensis. However, these two species are with somewhat irregular, narrow septal foldings, whereas our specimens have consistently high and round septal loops. In addition, our specimens differ from Rc. kalaikuchensis by smaller form ratio, and from Rc. longjiangensis by much heavier axial fillings.

Rugosochusenella cf. paragregaria (Rauser-Chernousova, 1940)

(Fig. 5C)

Description: Shell elongate fusiform with pointed poles. 6-7.5 volutions, 4.10-4.71 $\mathrm{mm}$ long and 1.18-1.41 mm wide with form ratio 3.06-3.96:1. Proloculus 0.07-0.13 mm in diameter. Inner 3-4 volutions very tight with plane septa. Septa strongly and irregularly folded in later stage. Chomata rather obsolete in juvenarium and absent in adult stage. Axial fillings heavily developed in polar area of inner volutions and in polar and nearby slope region of outer whorls. Spirotheca undulated.

Remarks: Our specimens are essentially identical to Rc. paragregaria, but have a larger form ratio.

Rugosochusenella sp. A

(Fig. 5E)

Description: Shell almost rhomboid with convex median portion and very blunt poles. 5.5-6.5 volutions, $2.82-3.05 \mathrm{~mm}$ long and $1.18-1.54 \mathrm{~mm}$ wide with form ratio 1.83-2.59:1. Proloculus 0.08-0.1 mm in diameter. Inner 3 volutions very tight and slender fusiform. Septal plane in inner 2 volutions, become poorly fluted in 3rd 
volution and strongly fluted in outer volutions and forming meshwork in polar ends. Chomata not observed. Axial fillings moderately developed in polar area of outer volutions. Rugosity could be observed in inner volutions and undulation distinct in outermost whorls. The median part of spirotheca in the outermost volution peculiarly thickened.

Rugosochusenella sp. B

(Fig. 5D, G)

Description: Shell elongate fusiform with bluntly pointed poles. 6 volutions, $3.04 \mathrm{~mm}$ long and $0.85 \mathrm{~mm}$ wide with form ratio 3.58:1. Proloculus $0.08 \mathrm{~mm}$ in diameter. Inner volutions not very tight with plane septa. Septa in later whorls strongly fluted, forming meshwork in both polar ends. Chomata small in inner volutions and absent in later stage. Axial fillings moderately developed in polar area of outer volutions. Spirotheca strongly undulated in all parts of the shell throughout the ontogeny. Remarks: This specimen resembles Rc.pseudogregaria Bensh, 1962, but differs in much smaller size and smaller form ratio.

Genus Xiaoxinzhaiella Shi, Yang and Jin, 2005

Diagnosis: Test subspherical to spherical. Juvenile volutions rather tight with plane septa. Chomata obsolete. Wall thin in juvenarium but with distinct tectum and keriotheca in mature stage.

Remarks: Shi et al (2005) separated this genus from Rugososchwagerina. They argued that Xiaoxinzhai could be distinguished from Rugososchwagerina by rather compact earliest volutions with plane septa. The morphological contrast between Xiaoxinzhaiella and Rugososchwagerina is similar to that between Chusenella and Schwagerina.

Xiaoxinzhaiella subrotunda Huang, 2010

(Fig. 6P, Q) 
Description: Shell subspherical with convex median portion and blunt poles. The lateral slope becomes somewhat concave near poles. Large in size with 8.5-10 volutions, 6.86-7.45 $\mathrm{mm}$ long and 4.58-4.76 $\mathrm{mm}$ wide with form ratio 1.50-1.57:1. Proloculus spherical and $0.06-0.09 \mathrm{~mm}$ in diameter. Innermost 3-4 volutions very tightly coiled in slender fusiform shape with plane septa. Following 2-3 whorls gradually expand outwards into fusiform shape and outer ones expand into subspherical shape. The coiling of last whorl becomes relatively tight again. Septa fluted in the interim fusiform volutions and somewhat irregularly fluted in adult stage, forming meshwork in polar ends. Irregular septal folds low and round. Chomata not obvious throughout the ontogeny. Axial fillings poor and confined in polar region of inner whorls, forming two narrow bars along axis. Rugosity of spirotheca could be observed in some parts of the shell.

Remarks: This species could be easily differentiated from Xiaoxinzhaiella densa Shi et al., 2005 and X. xanzensis (Wang et al., 1981) by its larger form ratio. Occurrence: Shazipo Formation (Murgabian-Midian) of the Bawei Section in southern Baoshan Block, China.

Subfamily Schwagerininae Dunbar and Henbest, 1930

Genus Schwagerina Möeller, 1877

Diagnosis: Test robust fusiform, septal intensely fluted, wall of tectum and keriotheca. Chomata weak or absent.

Schwagerina aff. quasiregularis Sheng, 1963

(Fig. 6K)

Description: Shell fusiform with pointed poles. 6.5 volutions, $3.84 \mathrm{~mm}$ long and 1.58 $\mathrm{mm}$ wide with form ratio $2.43: 1$. Proloculus $0.07 \mathrm{~mm}$ in diameter. Septa strongly folded, septal loops mostly round, forming meshwork in polar region of outer 
volutions. Chomata small but distinct in first 3 volutions, absent in outer whorls. Axial fillings poorly developed, confined in polar region of innermost whorls. Remarks: This specimen is very similar to $S$. quasiregularis, but the latter has obviously bigger proloculus and heavier axial fillings.

\section{Schwagerina sp.}

(Fig. 6J)

Description: Shell fusiform with bluntly pointed poles. 5.5 volutions, $2.05 \mathrm{~mm}$ long and $1.1 \mathrm{~mm}$ wide with form ratio 1.86:1. Proloculus $0.08 \mathrm{~mm}$ in diameter. Septa strongly folded since the 3rd volution. Septal loops round and low, but become higher towards the polar region. Small meshwork of septal flution and small bar of axial fillings developed in polar area. Chomata absent in outer volutions, rather obsolete in juvenarium.

Remarks: This specimen is characterized by the small size. In this regard, it resembles S. pseudoyüi Zhang and Dong, 1986 (in Xiao et al., 1986). But the latter has a much larger form ratio and heavier axial fillings.

Genus Rugosofusulina Rauser-Chernoussova, 1937 emend. Zhang and Dong, 1986 (in Xiao et al., 1986)

Diagnosis: Test fusiform to subcylindrical. Wall composed of tectum and keriotheca. Wall surface rugose and undulation could be also observed in some parts of the wall. Chomata obsolete.

Rugosofusulina aff. aktjubensis Rauser-Chernousova, 1937

(Fig. 6B, F-I)

Description: Shell fusiform with very gentle lateral slopes and bluntly pointed poles. 3.5-4.5 volutions, 3.51-4.72 $\mathrm{mm}$ long and 1.57-2.00 $\mathrm{mm}$ wide with form ratio 2.36-3.05:1. Proloculus spherical and 0.20-0.27 $\mathrm{mm}$ in diameter. Septa in general 
strongly and regularly fluted, but less folded in median area. No axial fillings.

Chomata distinct in inner volutions. Rugosity occurs both in tectum and keriotheca in most parts of the shell, and undulation present in certain parts of the spirotheca. Remarks: Our specimens closely resemble Rf. aktjubensis, but are slightly smaller with generally regular septal flution. In contrast, the type specimens of $R f$. aktjubensis have obviously irregular septal foldings.

Rugosofusulina aff. paravalida Bensh, 1972

(Fig. 6A, C, E)

Description: Shell elongate fusiform with blunt poles. 5-6 volutions, 5.39-6.03 mm long and 1.78-2.01 mm wide with form ratio 2.78-3.3:1. Proloculus spherical and 0.16-0.22 $\mathrm{mm}$ in diameter. Septa strongly and somewhat irregularly fluted. Septal flution become high and stronger towards polar ends. Chomata obsolete in innermost volutions. Axial fillings very poor in polar area of the innermost volutions. Spirotheca mostly has rugosity structure and in certain parts undulated.

Remarks: Our specimens are essentially identical to $R f$. paravalida. Nevertheless, our specimens are devoid of axial fillings, whereas $R f$. paravalida is with distinct axial fillings in the inner volutions.

Rugosofusulina cf. aktjubensis Rauser-Chernousova, 1937

(Fig. 6D, M)

Description: Shell fusiform with blunt poles. 4.5 volutions, $3.7 \mathrm{~mm}$ long and $1.35 \mathrm{~m}$ wide with form ratio 2.73:1. Proloculus spherical, a bit irregular in form, $0.18 \mathrm{~mm}$ in diameter. Septa strongly and irregularly folded. No obvious chomata and axial fillings observed. Strong rugosity and undulation present in all parts of the shell.

Remarks: This specimen is similar to Rf. aktjubensis in test shape and size, but it could be easily differentiated by its much smaller width for corresponding volutions, as well as a smaller form ratio. Besides, this only specimen is incomplete thus 
provisionally assigned to $R f$. cf. aktjubensis.

Rugosofusulina sp.

(Fig. 6N)

Description: Shell elongate fusiform, with gently convex median portion on one side and slightly concave median part on the other side. Poles blunt. 4 volutions, $5.27 \mathrm{~mm}$ long and $1.31 \mathrm{~m}$ wide with form ratio 4.01:1. Proloculus in irregular shape, possibly due to the strong undulation of spirotheca. Septa strongly and rather irregularly folded, but less folded in the median area. No obvious chomata and axial fillings. Strong rugosity and undulation present in all parts of the shell, especially in the outermost volutions.

Superfamily VERBEEKINACEA Staff and Wedekind, 1910

Family VERBEEKINIDAE Staff and Wedekind, 1910

Subfamily Kahlerininae Leven, 1963

Genus Kahlerina Kochansky-Devidé and Ramovs, 1955

Diagnosis: Test nautiloid to subspherical with round periphery. Septa generally plane.

Wall thick with tectum and keriotheca in mature stage. Tunnel bordered by asymmetrical chomata in outer volutions.

Kahlerina sp. indet.

(Fig. 6O)

Description: Shell spherical, 5 volutions and about $5.29 \mathrm{~mm}$ wide. Whorls evenly expand outwards. Septa plane. Spirotheca very thick, reaching $0.25 \mathrm{~mm}$ in thickness in the penultimate volution.

Remarks: Only one available sagittal section renders the precise specific determination impossible. Judging from the volution number and width, this specimen 
possibly belongs to Kahlerina minima Sheng, 1963.

Family NEOSCHWAGERINIDAE Dunbar and Condra, 1927

Subfamily Neoschwagerininae, Dunbar and Condra, 1927

Genus Neoschwagerina Yabe, 1903

Diagnosis: Test fusiform to ovoid with blunt poles. Septa plane. Axial septula appear early in development, transverse septula well developed, but no secondary transverse septula. Wall of tectum and thick keriotheca. Parachomata poor.

Neoschwagerina sp. indet.

(Fig. 6L)

Description: Shell $4.43 \mathrm{~mm}$ wide with 9 volutions. Proloculus unseen. Septa and axial septula distinct in the almost sagittal section. Rudimentary axial septula appear in inner volutions, number of axial septula one or two in outer volutions. Septula are generally slender but of variable length. Spirotheca consists of tectum and thick keriotheca. Thickness of wall could reach $0.15 \mathrm{~mm}$ in mature stage.

Remarks: This specimen was listed as Afghanella in Huang et al. (2015b). After reexamination, we realized that this specimen is characterized by moderately developed axial septula and thick spirotheca. Afghanella is supposed to have more septula between primary septa in outer volutions and relatively thin spirotheca. Thus, we here reassign this specimen to Neoschwagerina. During the development of Neoschwagerina phylogeny, rudimentary axial septula only appeared in outer whorls in primitive species, e.g., $N$. simplex. The number of axial septula became increasingly numerous between primary septa in outer shell and could be up to 1-3 in moderate species (e.g., N. carticulifera) and 3-5 in advanced forms (e.g., $N$. margaritae) (Kanmera, 1957; Ozawa, 1970). Judging from the development of axial septula, this specimen very likely represents one intermediate species of Neoschwagerina. 


\section{Acknowledgements}

Dr. Yi-Chun Zhang, another anonymous reviewer, and the editor are appreciated for their constructive comments, which significantly improved the manuscript. We are also indebted to Yi-Zhao Wang for his participation in the fieldwork. Financial supports for this study are from National Science Foundation of China (No. 41002007, 41372008, 41272043), Chinese Geological Survey (12120115070401).

\section{References}

Baranova, D.V., Kabanov, P.B., 2003. Facies distribution of fusulinoid genera in the Myachkovian (Upper Carboniferous, Upper Moscovian) of southern Moscow Region. Rivista Italiana di Paleontologia e Stratigrafia 109, 225-239.

Baranova, D.V., Kabanov, P.B., Alekseev, A.S., 2014. Fusulinids (Foraminifera), lithofacies and biofacies of the Upper Moscovian (Carboniferous) of the southern Moscow Basin and Oka-Tsna Swell. Paleontological Journal 48, 701-849.

Belasky, P., Stevens, C.H., Hanger, R.A., 2002. Early Permian location of western North American terranes based on brachiopod, fusulinid, and coral biogeography. Palaeogeography, Palaeoclimatology, Palaeoecology 179, 245-266.

Bensh, F.R., 1962. Late Carboniferous and Early Permian fusulinids of northern Fergana. In: Verkhov, V.I., Garkovets, V.R., Knauf, V.I. et al. (Eds.), Stratigraphy and Paleontology of Uzebkistan and Neighboring Regions, Book 1. Publishing Office of the Academy of Uzbekistan, Tashkent, pp. 186-252 (in Russian).

Bensh, F.R., 1972. Upper Paleozoic Stratigraphy and Fusulinids of South Fergana. Fan Publishing House, Tashkent, 146 pp. (in Russian).

Chen, X., 1956. Fusulinidae of South China, Part II. Palaeontologica Sinica, New Series B 6, 1-71.

Davydov, V.I., 1986. Fusulinids of Carboniferous-Permian boundary beds of Darvas. In: Chuvashov, B.I., Leven, E.Y., Davydov, V.I. (Eds.), Carboniferous-Permian Boundary Beds of the Urals, Pre Urals, and Central Asia. Nauka, Moscow, pp. 103-125 (in Russian). 
Davydov, V.I., Arefifard, S., 2007. Permian fusulinid fauna of peri-Gondwanan affinity from the Kalmard Region, East-Central Iran and its significance for tectonic and paleogeography. Palaeontologia Electronica 10, 1-40.

Davydov, V.I., Haig, D.W., McCartain, E., 2013. A latest Carboniferous warming spike recorded by a fusulinid-rich bioherm in Timor Leste: Implications for east Gondwana deglaciation. Palaeogeography, Palaeoclimatology, Palaeoecology 376, $22-38$.

Dawson, O., Racey, A., 1993. Fusuline-calcareous algal biofacies of the Permian Ratburi Limestone, Saraburi, Central Thailand. Journal of Southeast Asian Earth Sciences 8, 49-65.

Della Porta, G., Villa, E., Kenter, J.A.M., 2005. Facies distribution of fusulinida in a Bashkirian-Moscovian (Pennsylvanian) carbonate platform top (Cantabrian mountains, NW Spain). Journal of Foraminiferal Research 35, 344-367.

Deprat, J., 1912. Sur deux genres nouveaux de fusulinidés de l'Asie orientale, intéressants au point de vue phylogénetique. Compte Rendu hebdomadaire des séances de l'Académie des Sciences, Paris 154, 1548-1550.

Deprat, J., 1913. Étude des fusulinidés de Chine et d'Indochine et classification des calcaires à fusulines $\left(\mathrm{II}^{\mathrm{e}}\right)$. Les fusulinidés des calcaire carbonifériens et permiens du Tonkin, du Laos et du Nord-Annam. Memoires du Service Geologique de L'Indochine 2, 1-71.

Dunbar, C.O., Condra, G.E., 1927. The fusulinidae of the Pennsylvanian system in Nebraska. Bulletin of the Nebraska Geological Survey, Series 2, 2, 1-135.

Dunbar, C.O., Henbest, L.G., 1930. The fusulinid genera Fusulina, Fusulinella and Wedekindella. American Journal of Science, Series 5, 20, 357-364.

Dunbar, C.O., Skinner, J.M., 1937. Permian fusulinidae of Texas. The University of Texas Bulletin 3, 517-825.

Fang, R.S., Fan, J.C., 1994. On the cold water coral Lytvolasma fauna in Baoshan-Tengchong region. Yunnan Geology 13, 190-201 (in Chinese, with English abstract).

Fang, Z.J., Wang, Y.J., Shi, G.R., Zhou, Z.C., Xiao, Y.W., 2000. On the age of the 
Dingjiazhai Formation of Baoshan Block, western Yunnan, China — with a discussion on the redeposition hypothesis. Acta Palaeontologica Sinica 39, 267-278 (in Chinese, with English abstract).

Flügel, E., 2010. Microfacies of Carbonate Rocks, Second Edition. Springer-Verlag, Berlin, 984 pp.

Geological Survey Team of Yunnan, 1990. Regional Geological Reports of the Geological Map of Yanzitou, Menggong, Nansan and Gantang Sheet (1:50 000). Bureau of Geology and Mineral Resources of Yunnan Province, Kunming, pp. 92-125 (in Chinese).

Groves, J.R., 1991. Fusulinacean biostratigraphy of the Marble Falls Limestone (Pennsylvanian), western Llano region, Central Texas. Journal of Foraminiferal Research 21, 67-95.

Hottinger, L., 2006. Illustrated glossary of terms used in foraminiferal research. Notebooks on Geology - Memoir 2, 1-126.

Hsu, Y.C., 1942. On the type species of Chusenella. Bulletin of the Geological Society of China 22, 175-176.

Huang, H., 2010. Biostratigraphic and paleogeographic study of Permian fusulinids and Shanita fauna (foraminifera) from the Baoshan Block, western Yunnan. $\mathrm{PhD}$ Dissertation, Institute of Geology, Chinese Academy of Geological Sciences, Beijing, 165 pp. (in Chinese, with English abstract and systematic description).

Huang, H., Jin, X.C., Shi, Y.K., Yang, X.N., 2007. Middle Permian fusulinids from the Xainza area of the Lhasa Block, Tibet. Acta Palaeontologica Sinica 46, 62-74. (in Chinese, with English abstract)

Huang, H., Jin, X.C., Shi, Y.K., Yang, X.N., 2009. Middle Permian western Tethyan fusulinids from southern Baoshan Block, western Yunnan, China. Journal of Paleontology 83, 880-896.

Huang, H., Jin, X.C., Shi, Y.K., 2015a. A Verbeekina assemblage (Permian fusulinid) from the Baoshan Block in western Yunnan, China. Journal of Paleontology 89, 269-280.

Huang, H., Shi, Y.K., Jin, X.C., 2015b. Permian fusulinid biostratiraphy of the 
Baoshan Block in western Yunnan, China with constraints on paleogeography and paleoclimate. Journal of Asian Earth Sciences 104, 127-144.

Jin, X.C., 1994. Sedimentary and Paleogeographic Significance of Permo-Carboniferous Sequences in Western Yunnan, China. Geologisches Institut der Universitaet zu Koeln Sonderveroeffentlichungen, Koeln, 136 pp.

Jin, X.C., Yang, X.N., 2004. Paleogeographic implications of the Shanita-Hemigordius fauna (Permian foraminifer) in the reconstruction of Permian Tethys. Episodes 27, 273-278.

Jin, X.C., Huang, H., Shen, Y., Wang, Y.Z., 2008. Subdivision and correlation of Mid-Late Permian successions of the Baoshan Block, western Yunan: Status and problems. Acta Geoscientica Sinica 29, 533-541 (in Chinese, with English abstract).

Kahler, F., Kahler, G., 1979. Fusuliniden (foraminifera) aus dem Karbon und Perm von Westanatolien und dem Iran. Mitteilungen Österreichische Geolgische Gesellschaft 70, 187-269 (in German).

Kanmera, K., 1957. Revised classification of Cancellina and Neoschwagerina, and evolution of Sumatrininae and Neoschwagerininae. Memoirs of the Faculty of Science, Kyushu University, Series D: Geology 6, 47-64.

Kidwell, S.M., Bosence, D.W., 1991. Taphonomy and time-averaging of marine shelly faunas. In: Allison, P.A., Briggs, D.E.G. (Eds.), Taphonomy: Releasing the Data Locked in the Fossil Record. Plenum Press, New York, pp. 116-211.

Kobayashi, F., 1997. Middle Permian fusulinacean faunas and paleogeography of exotic terranes in the Circum-Pacific. In: Ross, C.A., Ross, J.R.P., Berenckle, P.L. (Eds.), Late Paleozoic Foraminifera, Their Biostratigraphy, Evolution and Paleoecology, and the Mid-Carboniferous Boundary. Cushman Foundation for Foraminifera Research, Special Publication 36, pp. 77-80.

Kobayashi, F., 2011. Permian fusuline faunas and biostratigraphy of the Akasaka Limestone (Japan). Reveu de Paléobiologie, Genéve 30, 431-574.

Kobayashi, F., 2012. Middle and Late Permian foraminifers from the Chichibu Belt, Takachiho area, Kyushu, Japan: Implications for faunal events. Journal of 
Paleontology 86, 669-687.

Kobayashi, F., Ishii, K.I., 2003. Permian fusulinaceans of the Surmaq Formation in the Abadeh region, central Iran. Rivista Italiana di Paleontologia e Stratigrafia $109,307-337$.

Kochansky-Devidé, V., Ramovš, A., 1955. Neoschwagerinski skladi in njih fuzulinida favna pri Bohinjski Beli in Bledu. Slovenska Akademiia Znanosti Umetnosti, Razpred Priodoslovne Vede, Razprave, Classis 4 (Natural History) 3, 359-424 (in Serbo-Croatian and German).

Kotlyar, G.V., Zakharov, Y.D., Kropatcheva, G.S., Pronina, G.P., Chedija, I.O., Burago, V.I., 1989. Evolution of the Latest Permian Biota - Midian Regional Stage in the USSR. Nauka, Moscow, 185 pp. (in Russian).

Latt, T.T., Ueno, K., 2008. Permian fusuline fauna from the Plateau Limestone of the Lebyin area, eastern Myanmar: Biochronologic and paleobiogeographic assessments. In: Choowong, M., Thitimakorn, T. (Eds.), Proceedings of the International Symposia on Geoscience Resources and Environments of Asian Terranes (GREAT 2008). 4th IGCP 516 and 5th APJEG. Department of Geology, Chulalongkorn University, Bangkok, pp. 170-171.

Lee, J.S., 1933. Taxonomic criteria of fusulinidae with notes on seven new Permian genera. Memoris of the National Research Institute of Geology, Academia Sinica $14,1-32$.

Leven, E.J., 1963. On the phylogey of advanced fusulinids and subdivision of Tethyan upper Permian deposits. Issues of Micropaleontology 7, 57-70 (in Russian).

Leven, E.J., 1967. Stratigraphy and fusulinids of the Pamir Permian deposits. Transactions of the Paleontological Institute of the Academy of Science of the USSR 167, 1-224 (in Russian).

Leven, E.J., 1987. Systematics and phylogeny of the family Schubertellidae Skinner, 1931. Paleontological Journal 2, 30-40 (in Russian).

Leven, E.J., 1997. Permian stratigraphy and fusulinida of Afghanistan with their paleogeographic and paleotectonic implications. Geological Society of America, Special Paper 316, 1-134. 
Leven, E.J., 1998. Permian fusulinid assemblages and stratigraphy of the Transcaucasia. Rivista Italiana di Paleontologia e Stratigrafia 104, 299-328.

Leven, E.J., 2004. Fusulinids and Permian scale of the Tethys. Stratigraphy and Geological Correlation 12, 33-47.

Leven, E.J., Gorgij, M.H., 2011. Fusulinids and stratigraphy of the Carboniferous and Permian in Iran. Stratigraphy and Geological Correlation 19, 687-776.

Leven, E.J., Okay, A.I., 1996. Foraminifera from the exotic Permo-Carboniferous limestone blocks in the Karakaya complex, northwestern Turkey. Rivista Italiana di Paleontologia e Stratigrafia 102, 139-174.

Lin, J.X., 1984. Fusulinida. In: Institute of Geology and Mineral Resources of Yichang (Ed.), Biostratigraphy of the Yangtze Gorge Area. Geological Publishing House, Beijing, pp. 165-170 (in Chinese).

Liu, C.A., Xiao, X.M., Dong, W.L., 1978. Fusulinida. In: Geological Institue of Southwest China (Ed.), Paleontological Atlas of Southwest China, Guizhou Fascicle (2). Geological Publishing House, Beijing, pp. 12-95 (in Chinese). Loeblich, A.R., Tappan, H.N., 1988. Foraminiferal Genera and Their Classification. Van Nostrand Reinhold Company, New York, 433 pp.

Möeller, V.v., 1877. Über fusulinen und ähnliche foraminiferen-formen des russischen Kohlenkalkes. Neues Jahrbuch für Mineralogie, Geologie und Paläontologie 1877, 139-146.

Möeller, V.v., 1878. Die spiral-gewunden foraminiferen des russischen Kohlenkalkes. Memoirs of the Imperial Academy of Sciences, St. Petersbrug 25, 349-356.

Metcalfe, I., 2013. Gondwana dispersion and Asian accretion: Tectonic and palaeogeographic evolution of eastern Tethys. Journal of Asian Earth Sciences 66, $1-33$.

Miklukho-Maklay, A.D., 1949. Upper Paleozoic Fusulinids of Central Asia: Fergana, Darvaz and Pamir. Publishing House of Leningrad State University, Leningrad, 126 pp. (in Russian).

Nie, Z.T., Song, Z.M., 1983. Fusulinids of lower Permian Maokouian Longge Formation from Rutog, Xizang (Tibet), China. Journal of Wuhan College of 
Geology 19, 55-68 (in Chinese, with English abstract).

Ozawa, T., 1970. Notes on the phylogeny and classification of the Superfamily Verbeekinoidea (Studies of the Permian Verbeekinoidean Foraminifera - I).

Memoirs of the Faculty of Science, Kyushu University, Series D: Geology 20, $17-58$.

Ozawa, Y., 1925. Palaeontological and stratigraphical studies on the Permo-Carboniferous limestone of Nagato, part II, Palaeontology. Journal of College of Science, Imperial University of Tokyo 45, 1-90.

Ozawa, Y., 1927. Stratigraphical studies of the Fusulina limestone of Akasaka, Province of Mino. Journal of the Faculty of Science, Imperial University of Tokyo, Section II, 2, 1-162.

Rauser-Chernousova, D.M., 1937. Rugosofusulina - a new fusulinid genus. The Studies in Micropaleontology 1, 9-26 (in Russian).

Rauser-Chernousova, D.M., 1940. Stratigraphy of the Upper Carboniferous and Artinskian stage on the western slope of the Urals and contributions to the fusulinid fauna. Transactions of the Institute of Geological Sciences of the Academy Sciences of the USSR, Geological Series 7, 37-101 (in Russian, with English summary).

Rosovskaya, S.E., 1965. Fusulinida. In: Ruzhencev, V.E., Sartcheva, T.G. (Eds.),

Development and Change of Marine Organisms at the Boundary of Paleozoic and Mesozoic. Nauka, Moscow, pp. 137-146 (in Russian).

Ross, C.A., 1965. Late Pennsylvanian Fusulinidae from the Gaptank Formation, West Texas. Journal of Paleontology 39, 1151-1176.

Ross, C.A., 1969. Paleoecology of Triticites and Dunbarinella in Upper Pennsylvanian strata of Texas. Journal of Paleontology 43, 298-311.

Ross, C.A., 1982. Paleobiology of fusulinaceans. In: Mamet, B., Copeland, M.J. (Eds.), Proceedings of Third North American Paleontological Convention 2. S.N. Publishing Company, Montréal, pp. 441-445.

Ross, C.A., 1995. Permian fusulinaceans. In: Scholle, P.A., Peryt, T.M., Ulmer-Scholle, D.S. (Eds.), The Permian of Northern Pangea. Springer-Verlag, 
Berlin, pp. 167-185.

Shen, S.Z., Shi, G.R., Fang, Z.J., 2002. Permian brachiopods from the Baoshan and Simao Blocks in western Yunnan, China. Journal of Asian Earth Sciences 20, $665-682$.

Sheng, J.Z., 1962. Fusulinids in China. Science Publishing House, Beijing, 177 pp. (in Chinese).

Sheng, J.Z., 1963. Permian fusulinids of Kwangsi, Kueichow and Szechuan. Palaeontologia Sinica, New Series B 10, 1-247 (in Chinese and English).

Sheng, J.Z., 1965. Fusulinids from the western Hainan Island, Kwangtung Province. Acta Palaeontologica Sinica 11, 563-579 (in Chinese, with English abstract).

Sheng, J.Z., Sun, D.D., 1975. Fusulinids of the Qinghai Province, China. Geological Publishing House, Beijing, 96 pp. (in Chinese).

Sheng, J.Z., Zhang, L.X., Wang, J.H., 1988. Fusulinida. Science Press, Beijing, 420 pp. (in Chinese).

Shi, G.R., Archbold, N.W., Zhan, L.P., 1995. Distribution and characteristics of mixed (transitional) mid-Permian (late Artinskian-Ufimian) marine faunas in Asia and their palaeogeographical implications. Palaeogeography, Palaeoclimatology, Palaeoecology 114, 241-271.

Shi, Y.K., Yang, X.N., Jin, X.C., 2005. Restudy of the "Rugososchwagerina" of the Middle Permian Shazipo Formation from Xiaoxinzhai of Gengma, western Yunnan. Acta Palaeontologica Sinica 44, 535-544 (in Chinese, with English abstract).

Shi, Y.K., Jin, X.C., Huang, H., Yang, X.N., 2008. Permian fusulinids from the Tengchong Block, western Yunnan, China. Journal of Paleontology 82, 118-127. Shi, Y.K., Huang, H., Jin, X.C., Yang, X.N., 2011. Early Permian fusulinids from the Baoshan Block, western Yunnan, China and their paleobiogeographic significance. Journal of Paleontology 85, 489-501.

Skinner, J.W., 1931. Primitive fusulinids of the Mid-Continent region. Journal of Paleontology 5, 253-259.

Skinner, J.W., Wilde, G.L., 1965. Lower Permian (Wolfcampian) fusulinids from the 
Big Hatchet Mountains, southwestern New Mexico. Contributions from the Cushman Foundation for Foraminiferal Research 16, 95-104.

Skinner, J.W., Wilde, G.L., 1966a. New Permian fusulinids from Twin Lakes and San Juan Island areas, northwestern Washington. The University of Kansas Paleontological Contributions 4, 28-40.

Skinner, J.W., Wilde, G.L., 1966b. Permian fusulinids from Sicily. The University of Kansas Paleontological Contributions 8, 1-16.

Smith, A.B., Xu, J.T., 1988. Palaeontology of the 1985 Tibet Geotraverse, Lhasa to Golmud. Philosophical Transactions of the Royal Society of London, Series A, Mathematical and Physical Sciences 327, 53-105.

Staff, H.v., Wedekind, R., 1910. Der Oberkarbon foraminiferensapropelit Spitzbergens. Bulletin of the Geological Institution of the University of Upsala 10, $81-123$.

Stewart, W.J., 1963. The fusulinid genus Chusenella and several new species. Journal of Paleontology 37, 1150-1163.

Sugiyama, T., Toriyama, R., 1981. Coral and fusuline faunas from the Kabin Buri area, East Central Thailand. Geology and Palaeontology of Southeast Asia 22, 1-22. Sun, Q.L., Zhang, L.X., 1985. Early Permian fusulinids from Alge Mountain of Xinjiang. Acta Palaeontologica Sinica 24, 505-510 (in Chinese, with English abstract).

Thompson, M.L., 1935. The fusulinid genus Staffella in America. Journal of Paleontology 9, 111-120.

Thompson, M.L., 1946. Permian fusulinids from Afghanistan. Journal of Paleontology 20, 140-157.

Thompson, M.L., 1948. Studies of American fusulinids. University of Kansas Paleontological Contributions, Protozoa, Article 1, 1-184.

Thompson, M.L., Foster, C.L., 1937. Middle Permian fusulinids from Szechuan, China. Journal of Paleontology 11, 126-144.

Toriyama, R., 1975. Fusuline fossils from Thailand, part IX, Permian fusulines from the Rat Buri Limestone in the Khao Phlong Phrab area, Sara Buri, central 
Thailand. Memoirs of the Faculty of Science, Kyushu University, Series D: Geology 23, 1-116.

Toriyama, R., Kanmera, K., 1979. Fusuline fossils from Thailand; Part XII, Permian fusulines from the Ratburi Limestone in the Khao Khao area, Sara Buri, central Thailand. Geology and Palaeontology of Southeast Asia 20, 23-93.

Toriyama, R., Kanmera, K., Ingavat, R., 1969. Fusulinacean fossils from Thailand, part V, Neofusulinella from Thailand. Contributions to the Geology and Palaeontology of Southeast Asia 73, 15-32.

Ueno, K., 2001. Jinzhangia, a new Staffellid fusulinoidea from the Middle Permian Daaozi Formation of the Baoshan Block, West Yunnan, China. Journal of Foraminiferal Research 31, 233-243.

Ueno, K., 2003. The Permian fusulinoidean faunas of the Sibumasu and Baoshan blocks: Their implications for the paleogeographic and paleoclimatologic reconstruction of the Cimmerian Continent. Palaeogeography, Palaeoclimatology, Palaeoecology 193, 1-24.

Vachard, D., Miconnet, P., 1989. An assemblage with Upper Murgabian fusulinoids at Monte Facito (Southern Apennine, Italy). Revue de Micropaleontologie 32, 297-318 (in French, with English abstract).

Villa, E., Bahamonde, J.R., 2001. Accumulations of Ferganites (Fusulinacea) in shallow turbidite deposits from the Carboniferous of Spain. Journal of Foraminiferal Research 31, 173-190.

Wang, L.T., Dong, W.L., Ye, N.Z., Chen, W.Y., 1982. A discussion of the relationship between fusulinid ecology and hydrodynamic environment. Oil and Gas Geology 3, 231-239 (in Chinese, with English abstract).

Wang, X.D., Ueno, K., Mizuno, Y., Sugiyama, T., 2001. Late Paleozoic faunal, climatic, and geographic changes in the Baoshan block as a Gondwana-derived continental fragment in Southwest China. Palaeogeography, Palaeoclimatology, Palaeoecology 170, 197-218.

Wang, X.D., Shi, G.R., Sugiyama, T., 2002. Permian of West Yunnan, Southwest China: A biostratigraphic synthesis. Journal of Asian Earth Sciences 20, 647-656. 
Wang, Y.J., Zhou, J.P., 1986. New material of fusulinids from Xainza, Xizang.

Bulletin of Nanjing Institute of Geology and Palaeontology, Academia Sinica 10, 141-156 (in Chinese, with English abstract).

Wang, Y.J., Sheng, J.Z., Zhang, L.X., 1981. Fusulinids from Xizang of China. In: Xizang Scientific Expedition Team of Academia Sinica (Ed.), Palaeontology of Xizang. Science Press, Beijing, pp. 1-80 (in Chinese, with English abstract).

Wang, Y.Z., 1983. The characteristics and significance of Carboniferous gravel bed in Tengchong and Baoshan area, western Yunnan. Contribution to the Geology of the Qinghai-Xizang (Tibet) Plateau 11, 71-75 (in Chinese, with English abstract).

Wopfner, H., 1996. Gondwana origin of the Baoshan and Tengchong terranes of West Yunnan. In: Hall, R., Blundell, D. (Eds.), Tectonic Evolutions of Southeast Asia. Geological Society, London, Special Publications 106, pp. 539-547.

Wopfner, H., Jin, X.C., 2009. Pangea megasequences of Tethyan Gondwana-margin reflect global changes of climate and tectonism in Late Palaeozoic and Early Triassic times - A review. Palaeoworld 18, 169-192.

Wu, Z.P., Yang, X.N., 1998. A study on different fusulinid faunae of the Changme Stage, Southwest China. Acta Micropalaeontologica Sinica 15, 37-47 (in Chinese, with English abstract).

Xiao, W.M., Wang, H.D., Zhang, L.X., Dong, W.L., 1986. Early Permian Stratigraphy and Faunas in Southern Guizhou. The People's Publising House of Guizhou, Guiyang, pp. 70-199 (in Chinese, with English summary).

Yabe, H., 1903. On a fusulina-limestone with Helicoprion in Japan. Journal of Geological Society of Japan 10, 1-13.

Yan, J.X., Liang, D.Y., 2005. Early and Middle Permian paleoclimates of the Baoshan Block, western Yunnan, China: Insight from carbonates. Journal of Asian Earth Sciences 24, 753-764.

Yunnan Bureau of Geology and Mineral Resources, 1995. Atlas of the Sedimentary Facies and Palaeogeography of Yunnan. Yunnan Science and Technology Press, Kunming, 228 pp (in Chinese).

Zhang, L.X., 1963. Upper Carboniferous fusulinids from the Kepin and adjacent areas 
of Xinjiang. Acta Palaeontologica Sinica 11, 36-70 (in Chinese and Russian).

Zhang, L.X., 1982. Fusulinids of eastern Qinghai-Tibet Plateau. In: Bureau of Geology and Mineral Resources of Sichuan Province, Nanjing Institute of Geology and Palaeontology, Chinese Academy of Science (Eds.), The Stratigraphy and Palaeontology of West Sichuan and East Tibet. Sichuan People's Publishing House, Chengdu, pp. 119-244 (in Chinese).

Zhang, L.X, Wang, Y.J., 1974. Fusulinida. In: Nanjing Institute of Geology and Palaeontology, Chinese Academy of Science (Ed.), Handbook of Stratigraphy and Paleontology in Southwest China. Science Press, Beijing, pp. 289-296 (in Chinese).

Zhang, Y.C., 2008. Middle and Late Permian Foraminfiera Faunas from the Lhasa Block and Exotic Limestone Blocks in Tibet and Palaeogeographical Implications. PhD Dissertation, Nanjing Institute of Geology and Paleontology, Graduate University of Chinese Academy of Sciences, Nanjing, 317 pp. (in Chinese, with English summary).

Zhang, Y.C., Cheng, L.R., Shen, S.Z., 2010. Late Guadalupian (Middle Permian) fusuline fauna from the Xiala Formation in Xainza County, central Tibet: Implication of the rifting tme of the Lhasa Block. Journal of Paleontology 84, 955-973.

Zhang, Y.C., Shi, G.R., Shen, S.Z., 2013. A review of Permian stratigraphy, palaeobiogeography and palaeogeography of the Qinghai-Tibet Plateau. Gondwana Research 24, 55-76.

Zhang, Z.C., 1992. A restudy of fusulinids from western Hainan Island. Acta Micropalaeontologica Sinica 9, 151-164 (in Chinese, with English abstract).

Zhang, Z.G., Chen, J.R., Yu, H.L., 1985. Early Permian stratigraphy and character of fauna in Xainza district, northern Xizang (Tibet), China. Contribution to the Geology of the Qinghai-Xizang (Tibet) Plateau 16, 117-135 (in Chinese).

Zhou, Z.R., Sheng, J.Z., 1994. Taxonomic Principles of Fusulinids — A Restudy of Permian Staffellids. Science Press, Beijing, 70 pp. (in Chinese, with English summary). 
Zhou, Z.R., Wang, Y.J., Sheng, J.Z., Zhu, K.Y., 2000. Neofusulinella lantenoisi Deprat, 1913, type species of the Permian fusulinid genus Neofusulinella, from Baoshan County, West Yunnan, China. Acta Palaeontologica Sinica 39, 457-465.

\section{Figure captions}

Figure 1. Index map showing the locality of the Bawei Section in the Baoshan Block, western Yunnan, China. (A) Tectonic division of western Yunnan; (B) and (C) detailed geographic and simplified geological map, respectively, in the vicinity of the Bawei Section.

Figure 2. Permian composite lithostratigraphy of the southern Baoshan Block in western Yunnan, China, showing occurrence levels of the studied fusulinids in the Bawei Section. Correlation of ICS (International Commission on Stratigraphy) and Tethyan Permian scale is based on Leven and Gorgij (2011).

Figure 3. Stratigraphic distribution of Guadalupian fusulinids in the Bawei Section from the southern Baoshan Block, western Yunnan, China.

Figure 4. Guadalupian fusulinids from the Bawei Section in southern Baoshan Block, western Yunnan, China, part 1. (A, D) Neofusulinella aff. praecursor Deprat, 1913, Cat. No. B2-9-4, B2-10-11. (B, C, E, F, K) Neofusulinella subglobosa Huang, 2010, Cat. No. B2-8-14, B2-14-2, B2-14-4, B2-9-5, B2-11-13; (B*) is magnification of (B), showing foramina and obscured wall structure. (G) Nankinella $\mathrm{cf}$. nanjiangensis Zhang and Wang, 1974, Cat. No. B2-8-20. (H, I) Nankinella cf. longgensis Nie and Song, 1983, Cat. No. B2-8-5, B2-10-2. (J) Neofusulinella cf. subglobosa Huang, 2010, Cat. No. B2-8-11. (L, Q) Yangchienia haydeni Thompson, 1946, Cat. No. B2-20-10, B2-21-4. (M, R) Yangchienia aff. haydeni Thompson, 1946, Cat. No. B2-9-6, 
B2-10-10. (N, O) Yangchienia hainanica Sheng, 1965, Cat. No. B2-11-6, B2-14-5. (P)

Staffella sp., Cat. No. B2-11-7. (S) Yangchienia thompsoni Skinner and Wilde, 1966b, Cat. No. B2-10-1.

Figure 5. Guadalupian fusulinids from the Bawei Section in southern Baoshan Block, western Yunnan, China, part 2. (A, B) Rugosochusenella aff. longjiangensis Lin, 1984, Cat. No. B2-2-17, B2-9-11. (C) Rugosochusenella cf. paragregaria (Rauser-Chernousova, 1940), Cat. No. B2-12-2. (D, G) Rugosochusenella sp. B, Cat. No. B2-20-8; (G) is magnification of the outer shell of this specimen, showing the undulation of the spirotheca. (E) Rugosochusenella sp. A, Cat. No. B2-21-5. (F) Chusenella cf. gracilis Rosovskaya, 1965, Cat. No. B2-9-1. (H) Chusenella wuhsüehensis (Chen, 1956), Cat. No. B2-25-2. (I, J) Chusenella tieni (Chen, 1956), Cat. No. B2-28-1, B2-37-1. (K) Chusenella aff. tieni (Chen, 1956), Cat. No. B2-20-5. (L) Chusenella aff. referta Skinner and Wilde, 1966a, Cat. No. B2-9-8. (M, P, R) Chusenella quasidouvillei Wang and Zhou, 1986, Cat. No. B2-20-3, B2-26-5, B2-20-6. (N, Q) Chusenella xarlensis Wang and Zhou, 1986, Cat. No. B2-11-12, B2-12-10. (O) Chusenella sp., Cat. No. B2-25-3.

Figure 6. Guadalupian fusulinids from the Bawei Section in southern Baoshan Block, western Yunnan, China, part 3. (A, C, E) Rugosofusulina aff. paravalida Bensh, 1972, Cat. No. B2-28-3, B2-23-3, B2-20-4. (B, F-I) Rugosofusulina aff. aktjubensis Rauser-Chernousova, 1937, Cat. No. B2-26-9, B2-29-4, B2-28-10, B2-28-5; (G) is magnification of the outer shell of $(F)$, showing the undulation of the spirotheca. (D, M) Rugosofusulina cf. aktjubensis Rauser-Chernousova, 1937, Cat. No. B2-21-7. (J) Schwagerina sp., Cat. No. B2-21-2. (K) Schwagerina aff. quasiregularis Sheng, 1963, Cat. No. B2-20-7. (L) Neoschwagerina sp. indet., Cat. No. B2-2-1. (N) Rugosofusulina sp., Cat. No. B2-23-1. (O) Kahlerina sp. indet., Cat. No. B2-14-6. (P, Q) Xiaoxinzhaiella subrotunda Huang, 2010, Cat. No. B2-8-19, B2-8-13.

Figure 7. Lithological features of the Bawei Section in southern Baoshan Block, 
western Yunnan, China. Microphotographs (c-h) show carbonate facies of fusulinid-bearing levels. (a) calcimudstone at the base of the section; (b) peloidal wackestone above the calcimudstone and below the occurrence of fusulinids; (c) dolomitic skeletal packstone, note numerous dolomites within the fusulinid shells; (d, e) skeletal packstone, (e) the close-up of (d) showing the muddy pseudospar with micritic relics; (f) skeletal wackestone; (g) a fusulinid shell covered with encrustation and infilled by micrite in inner volutions; (h) skeletal grainstone; (i) dolostone at the top of the section, magnified inset showing rhomboidal dolomite.

Figure 8. Schematic paleogeographic distribution of Middle Permian fusulinids of the Bawei and Nansan-Hewai areas in the southern Baoshan Block, western Yunnan, China. Note the dominance of staffellids in the Bawei area, while the prosperity of verbeekinids and neoschwagerinids in the Nansan and Hewai areas (modified from Geological Survey Team of Yunnan, 1990; Yunnan Bureau of Geology and Mineral Resources, 1995). The size of fusulinid tests not to scale. 


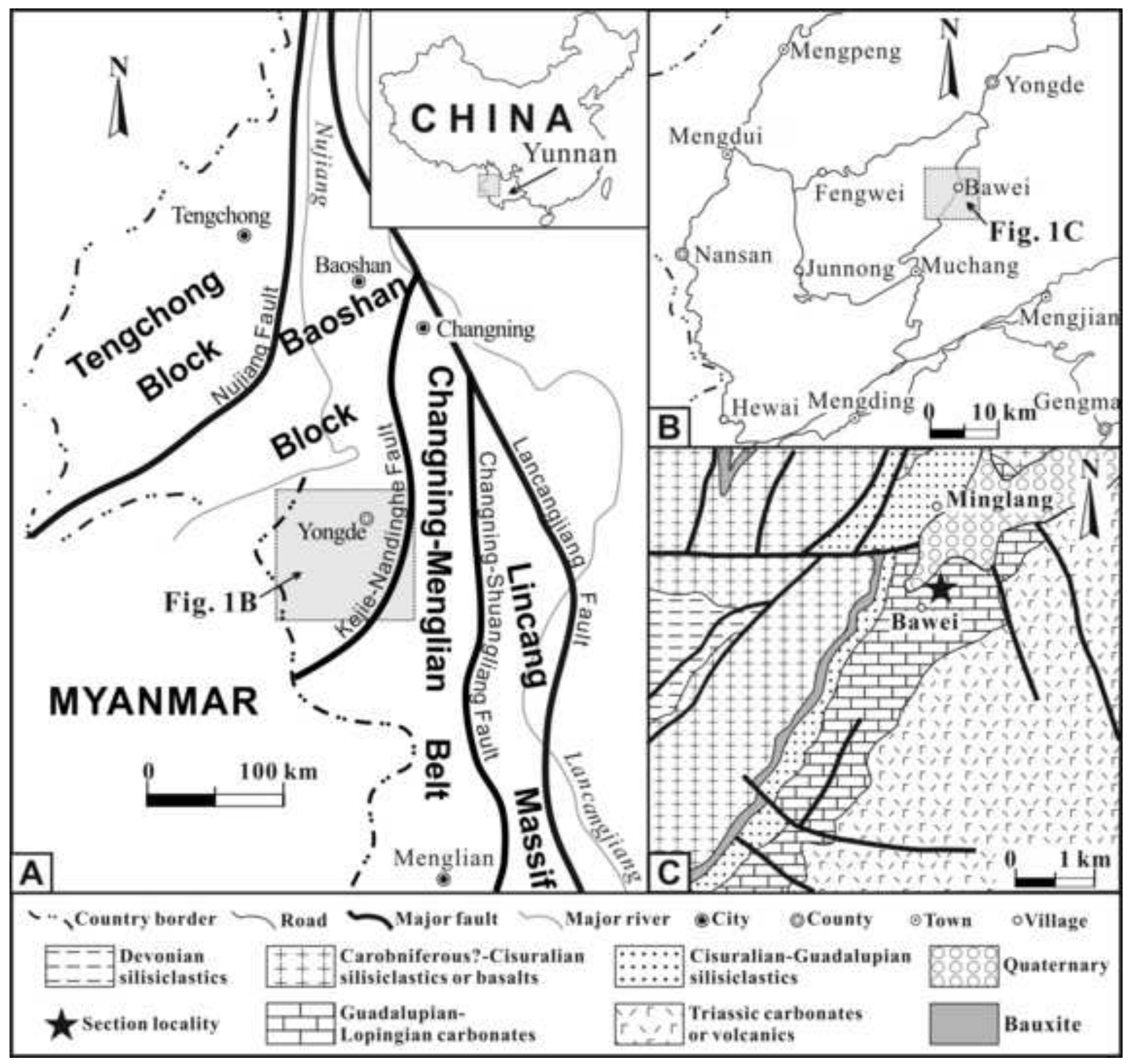




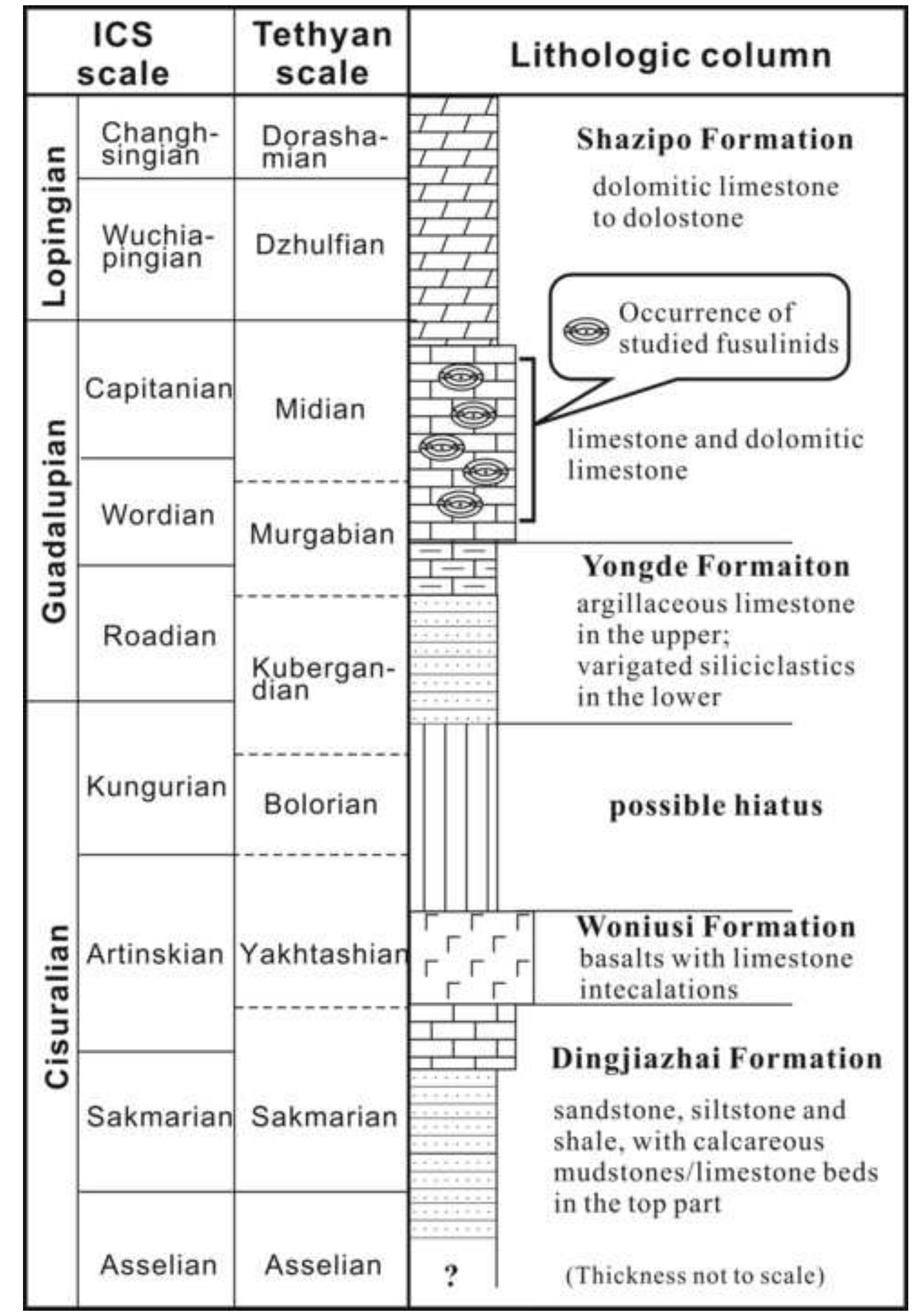




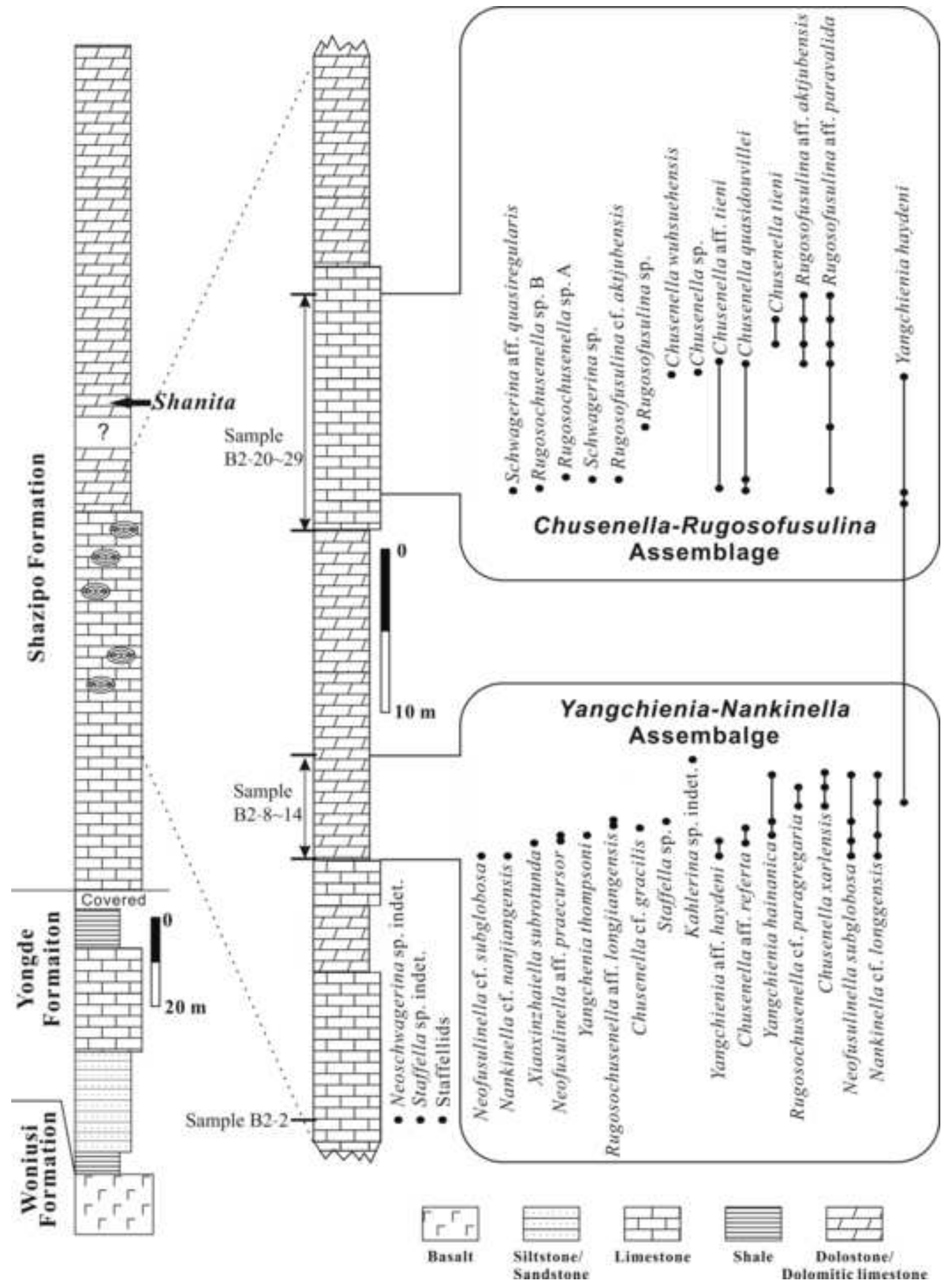



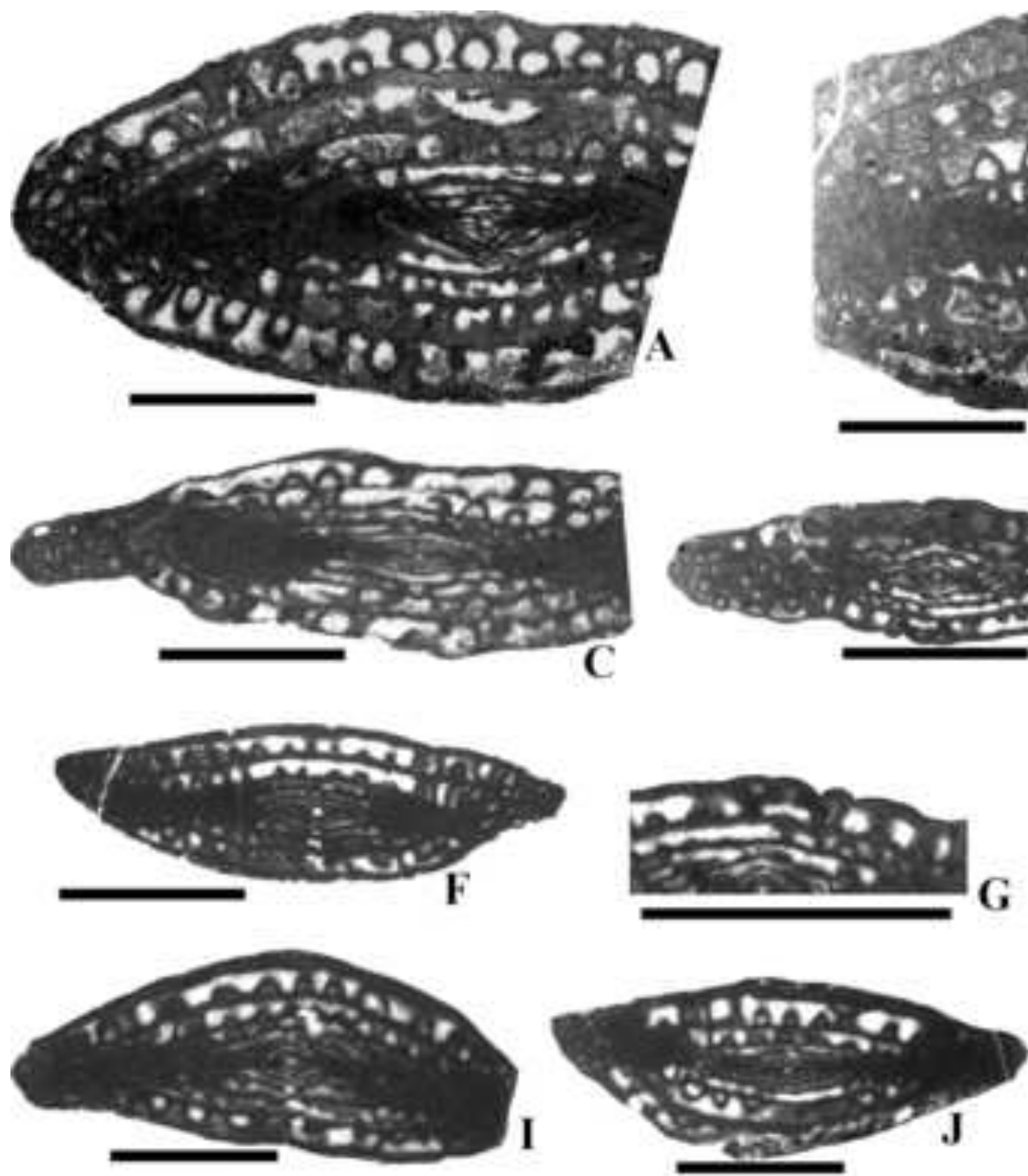

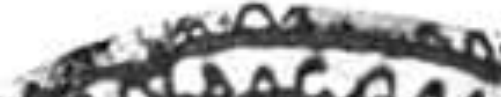
8 : 18.

- 35 cos $K$
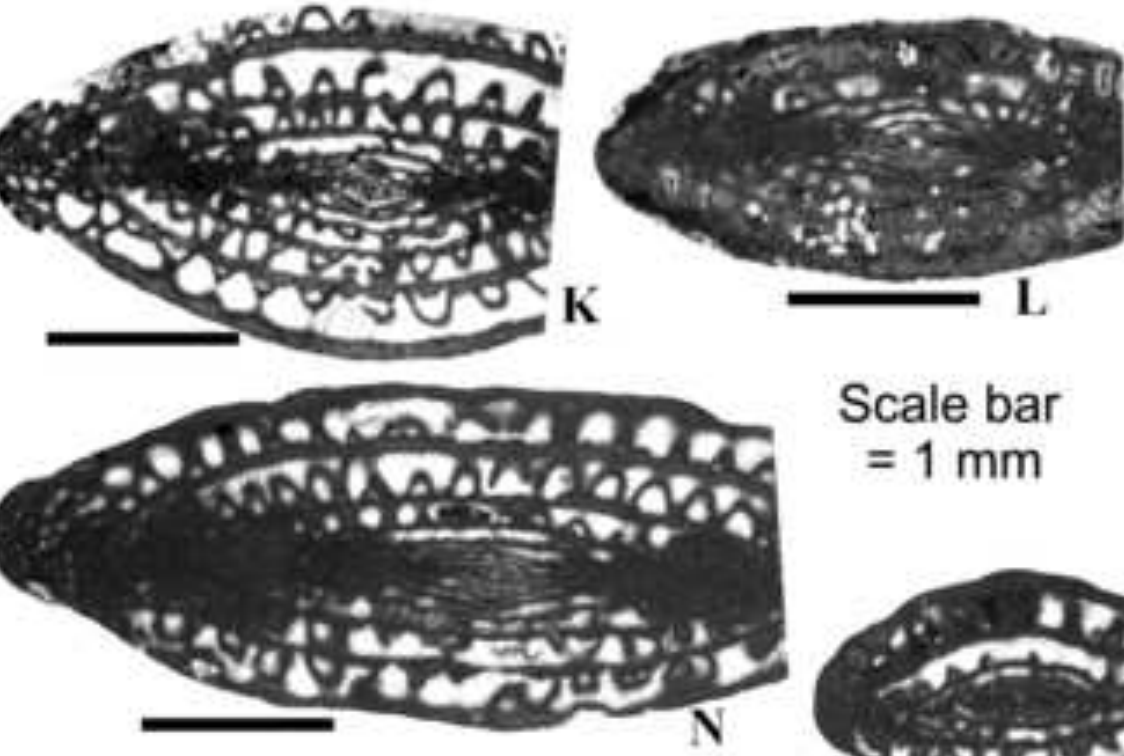

Scale bar $=1 \mathrm{~mm}$

D

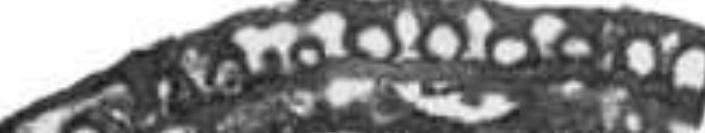
,
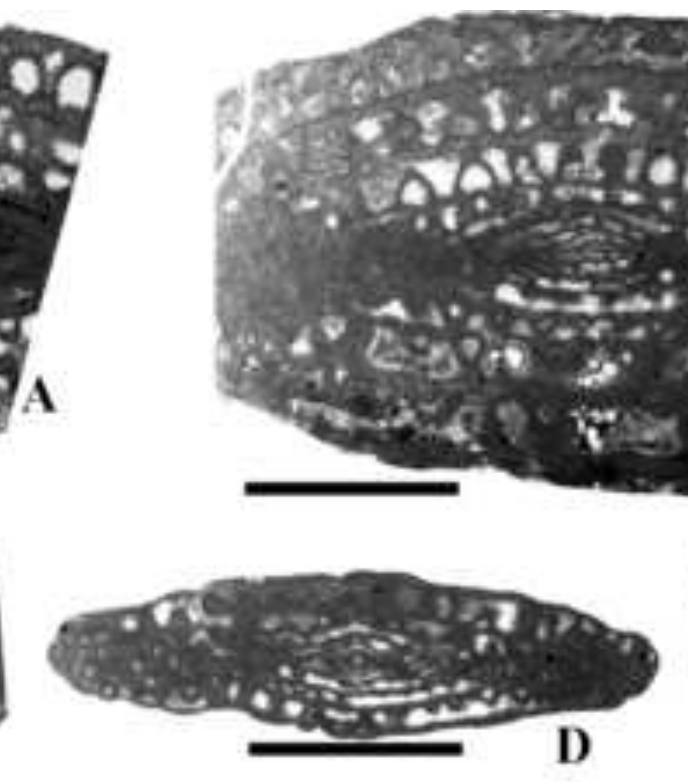
G

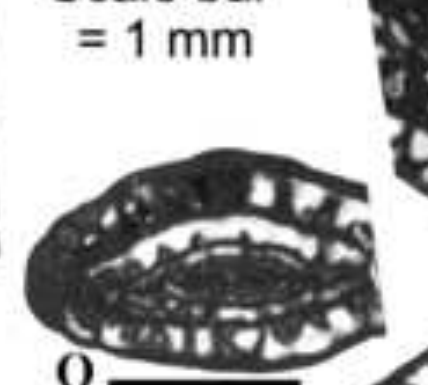

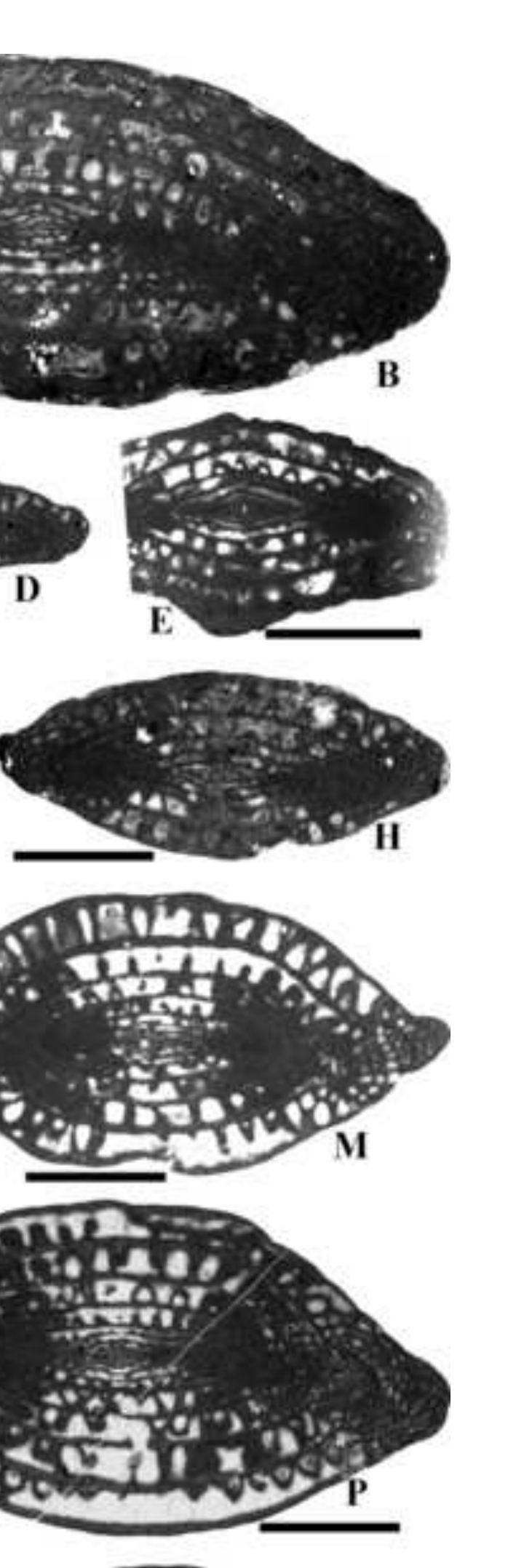

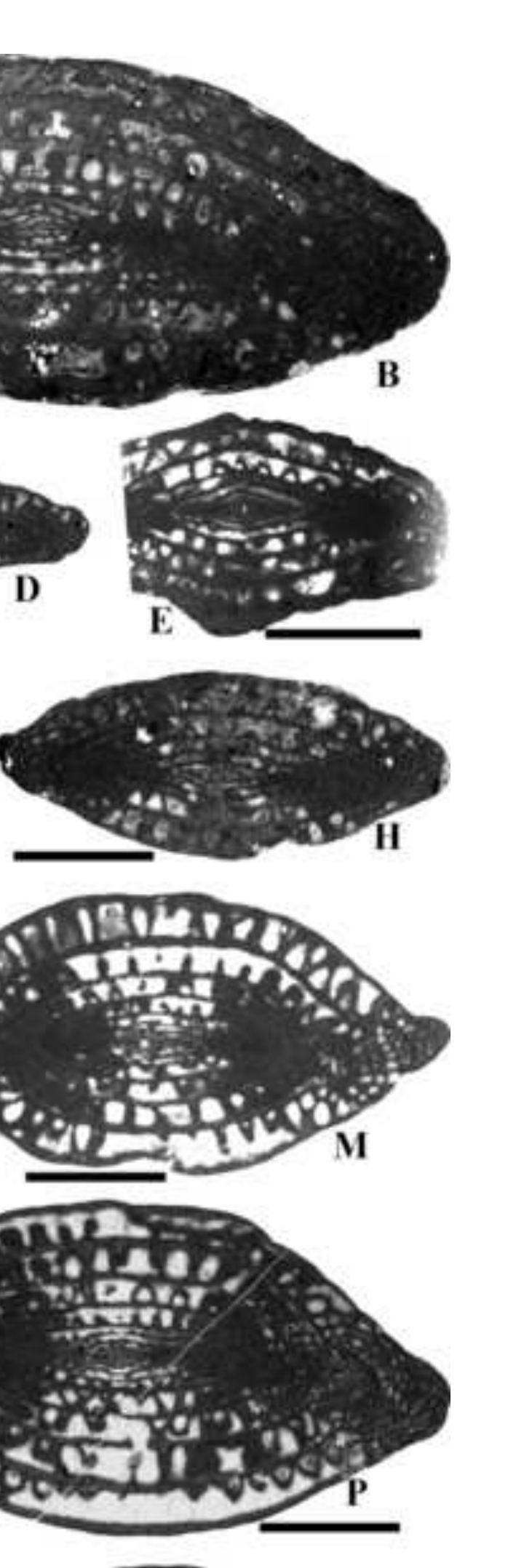

\section{B}
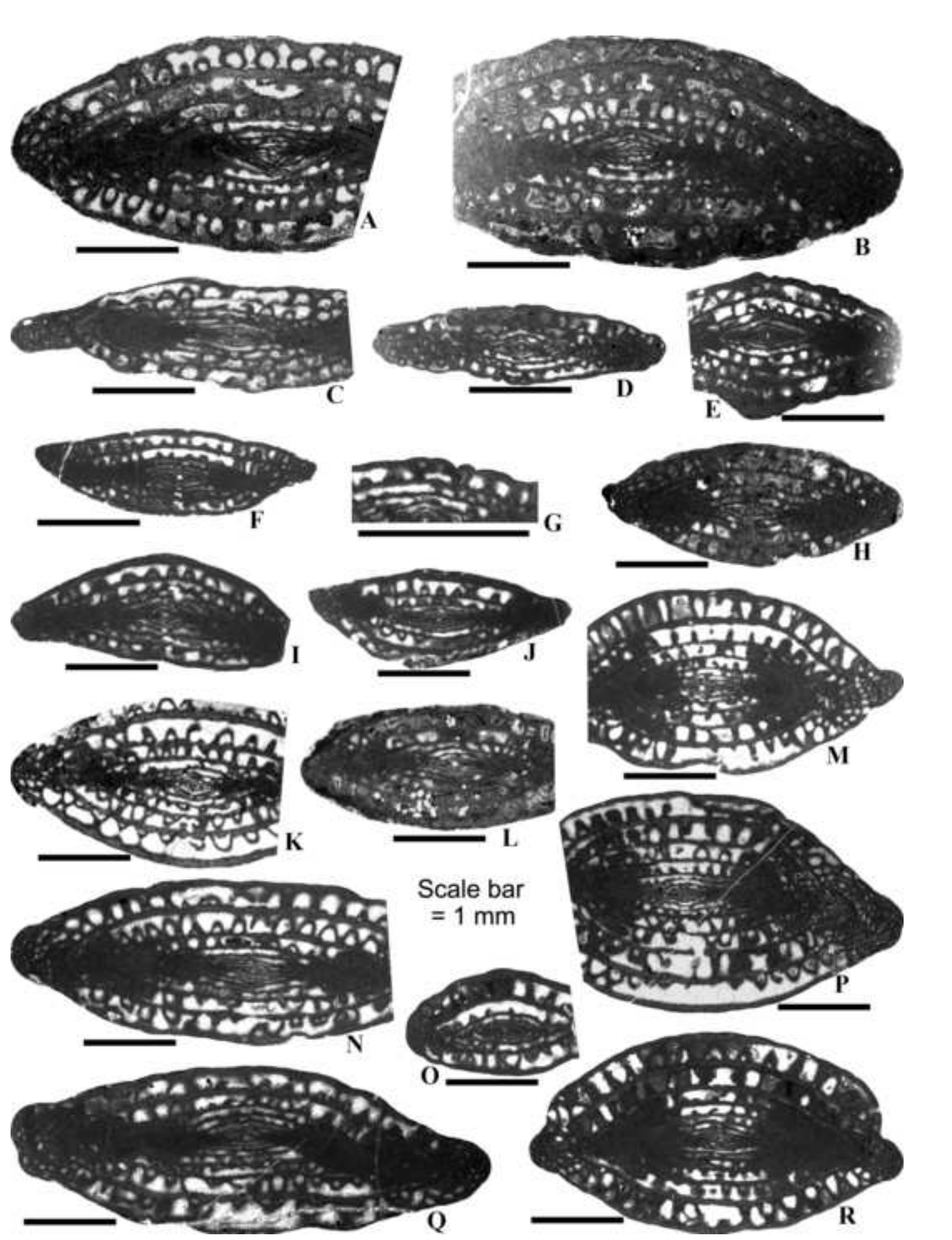
cosis: $P$

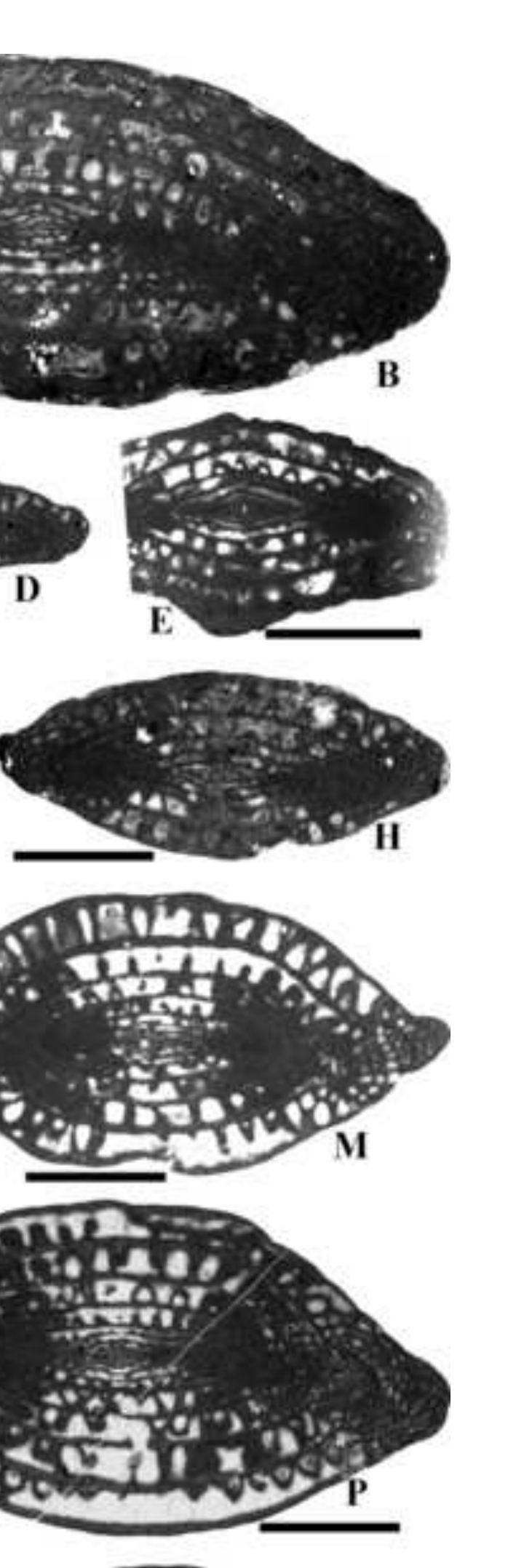




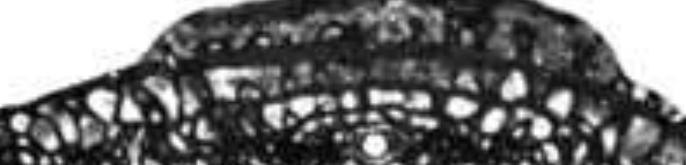

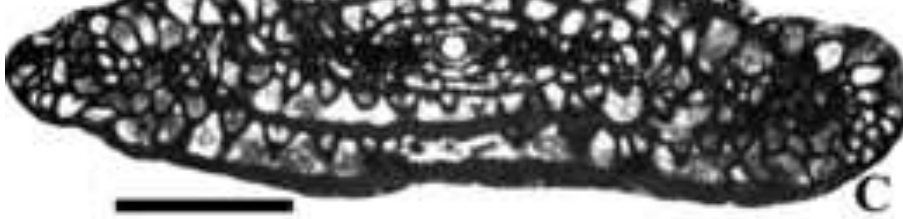

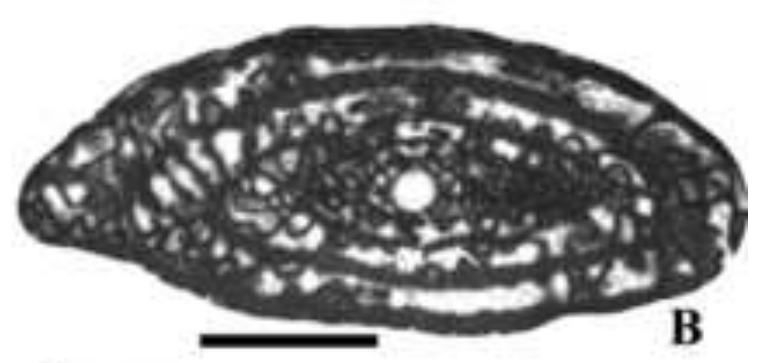

Scale bar $=1 \mathrm{~mm}$
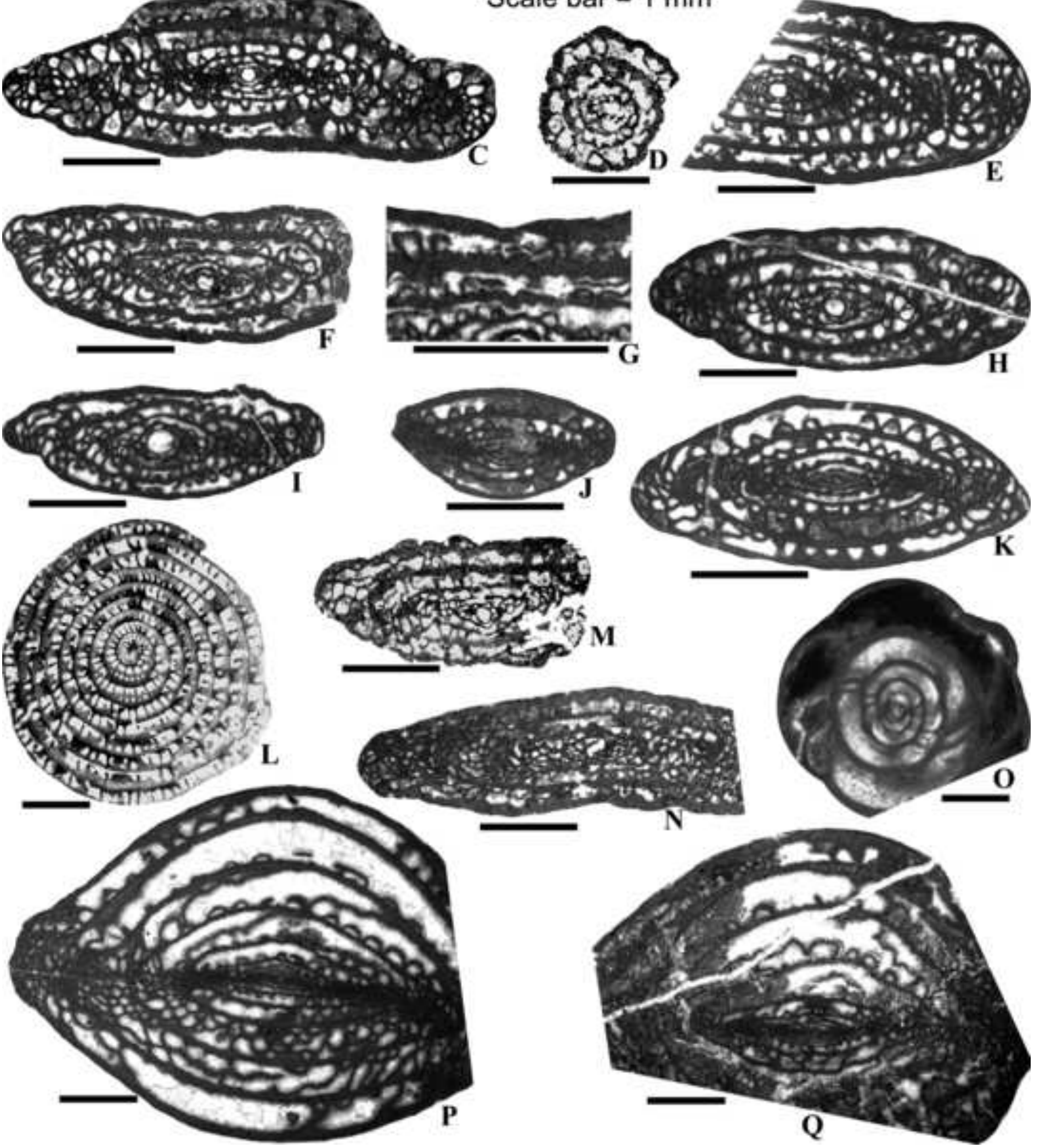

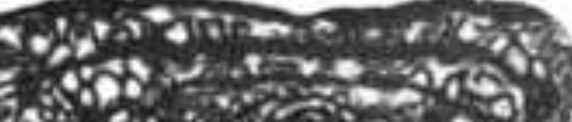

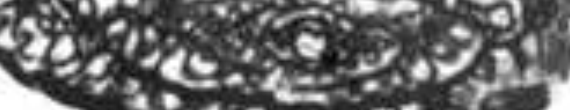
F
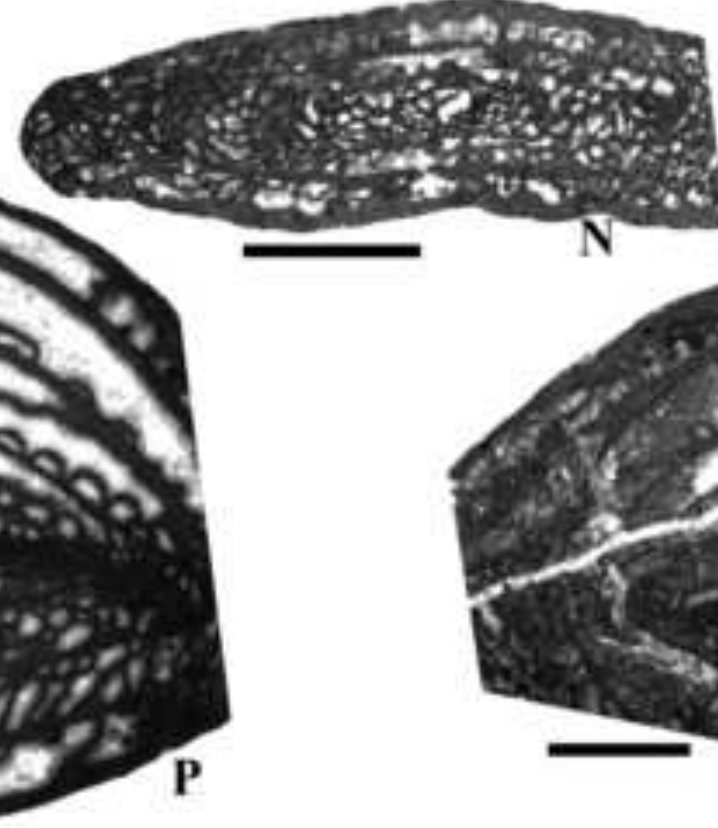


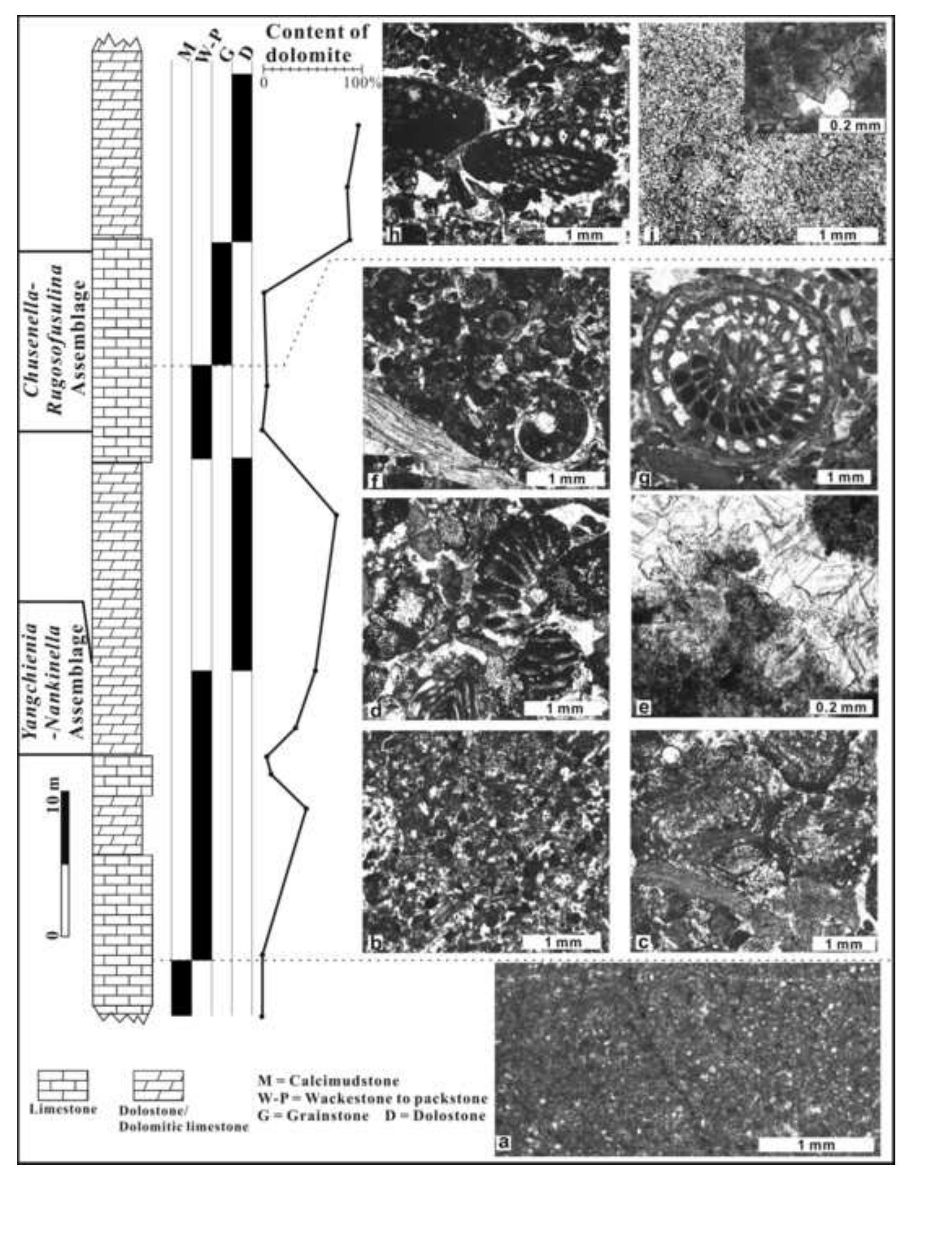

Figure 7

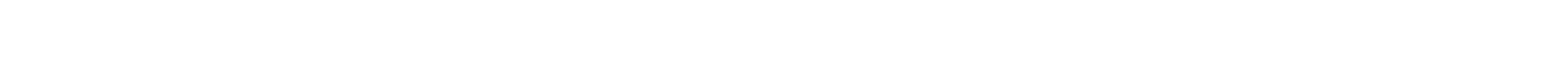




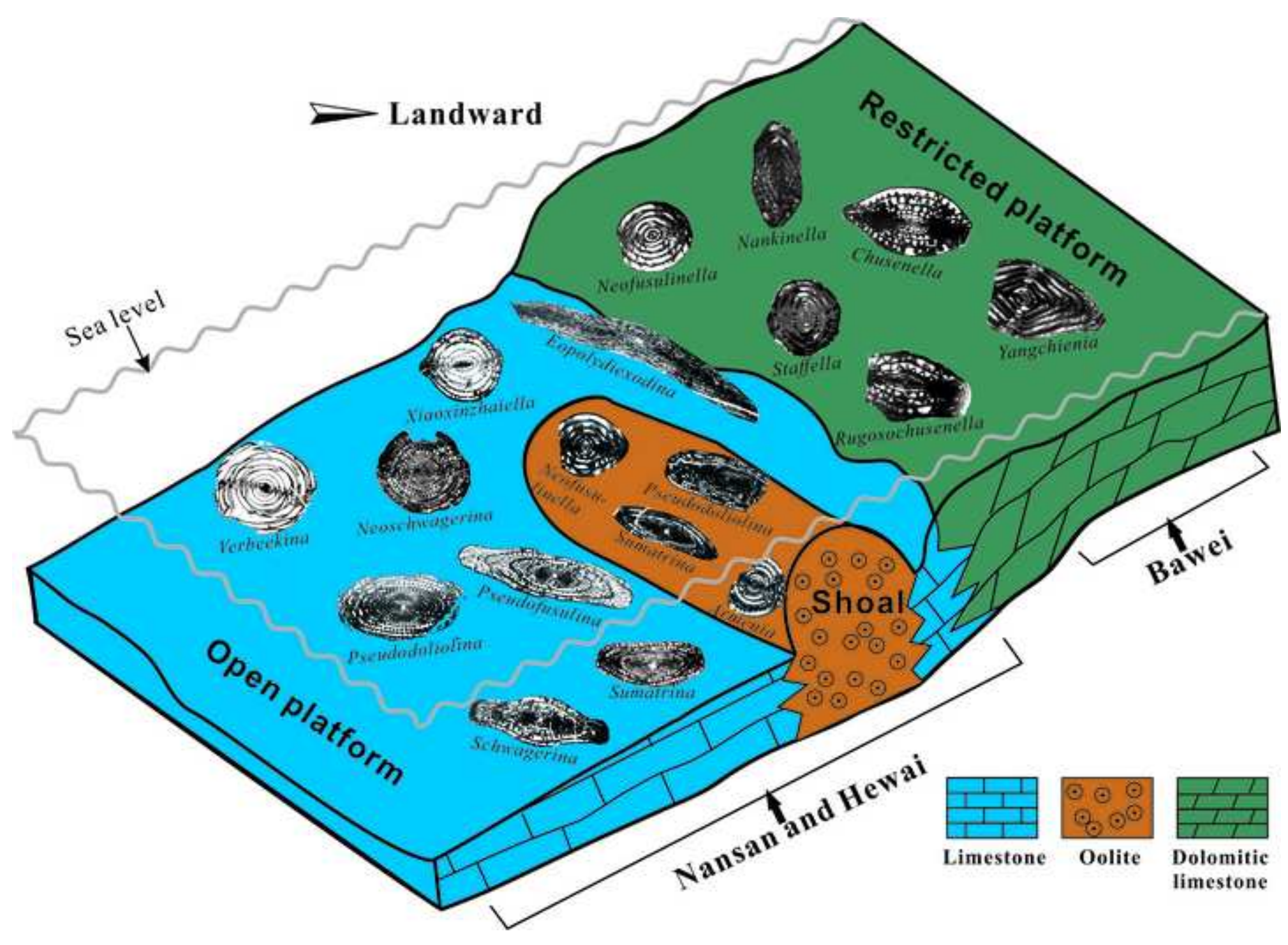

